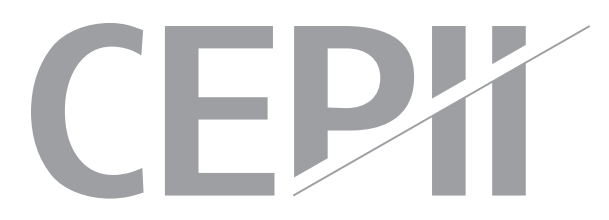

\title{
Trilemma, Dilemma and Global Players
}

Samuel Ligonnière

\section{Highlights}

- I provide empirical evidence that the trilemma does not morph into a dilemma.

- I clarify the role of the global financial cycle in the trilemma. The sensitivity to the Global Financial Cycle depends less on the fluctuations of these financial forces than on the presence of global investors and global banks.

-When the country goes to the worst trilemma configuration, i.e. financially open and with pegged exchange rates, the high presence of one of this kind of global player doubles the initial impact of financial forces. 


\section{Abstract}

This paper investigates the debate between the Mundellian trilemma and the dilemma. It focuses on the active role of the exchange rate regime. Overall, the global financial cycle magnifies the binding effect of financial openness on monetary policy autonomy, thus at the same time sharply reducing the effectiveness of the floating exchange rate regime to isolate the domestic economy against financial pressures. We provide empirical evidence that the trilemma does not morph into a dilemma. Furthermore, the sensitivity to the global financial cycle depends less on the fluctuations of these financial forces than on the presence of global investors and global banks.

Keywords

Trilemma, Dilemma, Exchange-Rate Regime, Global Financial Cycle, Global Players.

I JEL

E52, F32, F33, F38.

\section{Working Paper}

\section{CEPI}

CEPII (Centre d'Etudes Prospectives et d'Informations Internationales) is a French institute dedicated to producing independent, policyoriented economic research helpful to understand the international economic environment and challenges in the areas of trade policy, competitiveness, macroeconomics, international finance and growth.
CEPII Working Paper Contributing to research in international economics

(c) CEPII, PARIS, 2017

All rights reserved. Opinions expressed in this publication are those of the author(s) alone.

$\begin{array}{ll}\text { Editorial Director: } & \text { CEPII } \\ \text { Sébastien Jean } & \begin{array}{l}113, \text { rue de Grenelle } \\ 75007 \text { Paris }\end{array} \\ \text { Production: } & +33153685500 \\ \text { Laure Boivin } & \text { www.cepii.fr } \\ \text { No ISSN: } 1293-2574 & \text { Press contact: presse@ }\end{array}$


Trilemma, Dilemma and Global Players ${ }^{1}$

Samuel Ligonnière*

\footnotetext{
${ }^{1} \mathrm{~A}$ previous version of this paper has been drafted during the author's stay at CEPII in 2015 . This paper features an online appendix containing additional results and available on the author's website (Link).

I benefitted greatly from exchanges with Rémi Generoso, Jérôme Héricourt, Jean Imbs, Hubert Kempf, Farid Toubal, and participants at seminars at CREST, LEM and at Ecole Normale Supérieure Paris-Saclay. I am very grateful for the comments of Cécile Couharde and of Fabien Tripier, as discussants at the LEM Workshop External Imbalances and at the RIEF 17th Doctoral Meetings. Any remaining errors are mine.

*Université de Lille, LEM, UMR CNRS 9221, and ENS Paris Saclay; Email: samuel.ligonniere@ ens-paris-saclay.fr
} 


\section{Introduction}

After the massive unconventional monetary policies of the Federal Reserve and the European Central Bank (ECB) in 2009, Dilma Roussef described them as a monetary tsunami and the Brazilian Finance Minister Guido Mantega spoke of a currency war. Large capital inflows could generate appreciation pressures, trigger credit booms, and fuel speculative asset bubbles, as suggested by Mendoza and Terrones (2008) and Blanchard et al. (2015), among others. Conversely, the gradual withdrawal of the quantitative easing program announced by Ben Bernanke in the summer of 2013 has generally not simplified domestic monetary policy for policymakers. This taper tantrum has deepened financial vulnerabilities, leading to strong downward pressures on emerging currencies and increasing the likelihood and the strength of further domestic financial crises. Therefore, the uncertainty about a new taper tantrum and Yellen's strategy point out the urgent need which policymakers in emerging markets have of efficient tools to isolate their domestic financial markets from US monetary policy. The spillover effects from the Fed are large, because it drives global liquidity and because of the high level of comovement in asset prices, credit, and risk aversion around the world. This worldwide trend is called the Global Financial Cycle by Rey (2015), and could potentially destabilize trilemma trade-offs.

The traditional trilemma in Mundell (1963) has long been considered as the key toolkit for international macroeconomists. According to this view, countries have to choose two out of three objectives, namely monetary policy independence, fixity of the exchange rate regime, and perfect capital mobility. By contrast, Rey (2015) supports that this trilemma has rather become a dilemma: countries must choose between monetary policy independence and financial openness, regardless of the exchange rate regime. The idea behind this new configuration is that financial flows are transmitted independently of the exchange rate regime. The resilience of domestic economies depends more on the ability of volatile and potentially destabilizing capital flows to get in or out of domestic financial systems rather than on the decision between a peg, a crawling band, or a managed floating rate. This controversy has important implications for policymakers regarding global capital flows and the prevention of 
financial vulnerabilities. If the trilemma remains valid, researchers should focus on the right configuration between the exchange rate regime and financial openness. But if the dilemma is true, the effectiveness of various capital flow management strategies, such as targeted capital controls and the macroprudential regulation toolkit, becomes the major challenge. Following Forbes et al. (2015), Klein (2012), and Klein and Shambaugh (2015), the design of capital controls and their complementarity with other policies are still puzzling.

This paper demonstrate that there is no move from trilemma to dilemma. It is in line with an extensive empirical literature based on Shambaugh (2004), Obstfeld et al. (2005), and Aizenman et al. (2008). Klein and Shambaugh (2015) update this approach by taking into account intermediate situations such as soft pegs or temporary and targeted capital controls. I follow their recent classifications of financial openness and exchange rate regime to get the finest possible level of classification. They find that managing the exchange rate regime allows greater monetary policy autonomy than a modest closure of capital account. This empirical result is close to Farhi and Werning (2012) who model the interest of some capital controls for a small open economy with a fixed exchange rate to reintroduce the interest rate differential.

Concurrently, Rey (2015) and Passari and Rey (2015) try to support the dilemma in two steps. They prove the global financial cycle with this following sequence: US monetary policy drives the global risk aversion and uncertainty, proxied by the VIX, which in turn pushes international capital flows. These waves of flows are highly synchronized around the world and trigger financial domestic vulnerabilities in credit and asset markets. ${ }^{2}$ They then show that these vulnerabilities do not seem to be influenced by exchange rate regimes. Yet, this is only conjectural evidence and their sample bias in favor of advanced economies may be another reason for their mitigated results. By contrast, this paper provides explicit proof because I directly use monetary policy independence as the dependent variable, and rigorous exchange

\footnotetext{
${ }^{2}$ Recent empirical papers on global push and national pull factors also support the idea of the dilemma. Forbes and Warnock (2012) and Ghosh et al. (2014) point out the role of global factors that drive capital flows, in particular the VIX. Ahmed and Zlate (2014) find that capital flows are more and more sensitive to the interest rate differential and to global risk aversion. In addition, this paper is not the first to investigate the non-linearities related to the VIX: Nier et al. (2014) demonstrate that the VIX becomes the main driver of capital flows when it is very high, but they never use thresholds.
} 
rate classifications. ${ }^{3}$ In the same spirit, Miranda-Agrippino and Rey (2015) and Rey (2016) draw attention to the global financial cycle and the international transmission channels of US monetary policy through VAR analyses. At least three mechanisms emerged from Rey (2016), namely the international credit channel, the risk-taking channel, and the "fear of floating" channel. ${ }^{4}$.

The key contribution of this paper is to invalidate a gradual move from the trilemma to the dilemma: the increasing financial forces and linkages over time magnify the effects of financial openness but also of exchange rate management. The trilemma is worsened but does not disappear. My unbalanced sample covers 161 various countries characterized by a large variety of domestic monetary conditions from 1970 to 2013 which is sufficient to highlight trends and potential non-linearities. I take into account various national and global determinants of monetary policy independence and capture potential structural breaks. I test various assumptions to determine under which conditions there is a trilemma or dilemma. A rigorous interpretation of Rey (2015) links growing financial forces over time and a gradual move from trilemma to dilemma. Another interpretation is feasible: if the shift depends on the VIX, the trilemma is valid during the boom, i.e. with low risk aversion and little uncertainty, but it transforms itself into a dilemma during the bust. If it depends on the domestic exposure to the global financial cycle as suggested by Goldberg (2013) and by Cerutti et al. (2015), I investigate whether the presence of global players - global investors and global banks - worsen the trilemma or transform it into a dilemma.

A second contribution is to clarify the role of the global financial cycle in the trilemma. The sensitivity to the global financial cycle depends less on the fluctuations of these financial forces than on the domestic presence of global investors and global banks. When the country goes to the worst trilemma configuration, i.e. financially open and with pegged exchange rates,

\footnotetext{
${ }^{3}$ They use the coarse classification of Reinhart and Rogoff (2004), but their methodology compares official and dual markets. Therefore, their index gives a combination of both financial openness and exchange rate regime.

${ }^{4}$ The first operates through occasionally binding collateral constraints and highlights amplification effects Ãă la Lorenzoni (2008) The second puts forward the synchronization and the compression of risk premia around the world, following Bruno and Shin (2015b). The latter is the potentially disruptive answer of a Central Bank to a foreign monetary policy. It generates misallocation, especially through mortgage spreads.
} 
the high presence of one of this kind of global player doubles the initial impact of financial forces, especially for global banks. As a third result, I distinguish between the roles of global investors and global banks, and investigate them. The presence per se of global players generally will worsen the trilemma, and their presence associated with specific policymakers' decisions exacerbate these trade-offs. Global investors reinforce transmission channels between the exchange rate regime and monetary policy autonomy, but less so with financial openness, while global banks play a more active role for both policy decisions.

I survey the respective roles of the fluctuations and the exposure to this global financial cycle in this trilemma-dilemma debate. This paper is closely related to Goldberg (2013), Aizenman et al. (2016), Obstfeld (2015), Hofmann and Takàts (2015), Ricchi and Shi (2016), and Han and Wei (2016) who merge both approaches. Goldberg (2013) was the first to reconcile this debate between the trilemma and the dilemma through the growing role of global banks in the international financial system. By comparison, I investigate three determinants of these potential alterations of the trilemma, that is the level of the global financial cycle, the presence of global investors, and that of global banks. This literature has been influenced by Aizenman et al. (2016). They adopt a credible methodology to exhibit the determinants of the sensitivity of several financial variables, including the interest rate differential. They disentangle international, cross-country, and domestic factors. They find a greater sensitivity of interest rates for developing countries to those of more financially developed, advanced countries. ${ }^{5}$ I take a somewhat different approach, which is closer to Obstfeld (2015) and Hofmann and Takàts (2015), and focus on the real existing configuration between the trilemma and the dilemma. For their part, these two papers test the trilemma using the interest rate differential, time fixed effects or the VIX and distinguish between short-term and long-term rates. Obstfeld (2015) establishes the aftermath of the global financial cycle, especially for emerging countries but only for long-term rates, credit, and asset prices. The global financial

\footnotetext{
${ }^{5}$ Their proof of the trilemma view is questionable: the sensitivity of domestic emerging interest rates positively depends on a country's financial openness and, more surprisingly, on more floating exchange rate regimes. It is at odds with the trilemma, but they explain this result by the high correlation between these two choices: a country chooses a flexible exchange rate regime when it is willing to support financial pressures, that is with financial openness and well-developed domestic financial markets. As suggested by Ricchi and Shi (2016), their methodology supports rather the idea of monetary policy spillovers than a proof of the trilemma.
} 
cycle seems not to have a significant influence on short-term interest rates, shedding light on still prevailing monetary policy trade-offs. It contrasts with Hofmann and Takàts (2015) and this paper, because both expose a causal link from the VIX to short-term interest rates. As a result, I quantify the contribution of the VIX to the year fixed effect and how it reacts when global players are included to highlight the exposure to this cycle. The VIX only explains around $20-30 \%$ of the year fixed effect in this high temporal coverage. I also assess to what extent the comovement of short-term policy rates really implies autonomy because of the high synchronization of business cycles or domestic policy choices. It is in line with Ricchi and Shi (2016) and Han and Wei (2016). The latter include surprise components of the semiannual inflation and growth forecasts, whereas I compute the correlation of business cycles and inflation cycles. Their results are also complementary to mine: Han and Wei (2016) introduce asymmetry in the trilemma-dilemma debate by distinguishing between the increase and decrease of US policy interest rates, ${ }^{6}$ while I explore determinants of the global financial cycle.

The remainder of the paper is structured as follows. Section 2 describes the dataset. It explains the choice of exchange rate classifications and details the related methodology. Section 3 presents the estimation strategy and clarifies trilemma mechanisms. As further results, it investigates potential regime-switching through the global financial cycle. Section 4 lists some robustness checks, and Section 5 provides concluding remarks.

\section{Data}

This section provides details on data sources, including the different measures of the global financial cycle and of global players. My unbalanced panel database consists of 161 countries from 1970 to 2013 with 27.5 years per country on average. This sample of countries reflects all advanced economies and a large part of developing countries. Appendix 1 provides a list of the countries, data sources, and descriptive statistics.

\footnotetext{
${ }^{6}$ When the FED raises its interest rate, a more flexible exchange rate improves monetary policy independence. Yet, the opposite case is not true, suggesting a fear of appreciation. Nevertheless, they use a questionable data source on the exchange rate regime classification and they lump all pegged countries together. The same holds for financial openness, without a robustness check.
} 
Because of growing financial forces over time, long time coverage is necessary to expose potential non-linearities. Another motive is that sensitivities to the global financial cycle fundamentally depend on the depth of domestic financial markets, as suggested by Hofmann and Takàts (2015). Thus, the unbalanced panel is not a problem because some developing countries emerged belatedly in international monetary and financial systems. Besides, I adopt annual time frequency. Some variables are monthly or even daily, but some key variables only exist in annual frequency and make no sense in higher frequency.

\subsection{Monetary Policy Independence}

Monetary policy independence is generally measured by comovement in interest rates. I use the continuous index from Aizenman et al. (2008) which depends on the annual correlation between the monthly interest rates of domestic country $i$ and base country $j$. The base country is not necessarily US but depends on its own history. It is defined in Shambaugh (2004). I note monthly data by using $m \in[1,12]$. The monetary policy independence index is defined as follows:

$$
M I_{i t}=1-\frac{\operatorname{corr}\left(i_{i m t}, i_{j m t}\right)+1}{2}
$$

This index is normalized to be bounded between 0 and 1 . A perfect negative correlation represents perfect monetary policy independence with the index equal to 0 , while a perfect positive correlation means dependence. The process put forward by Aizenman et al. (2008) seems better than the use of a simple year interest rate differential for several reasons. First, the correlation between monthly interest rates is more informative than the first difference of year interest rate differential, used by Klein and Shambaugh (2015). Second, Aizenman et al. (2008) have taken precautions: they take into account medium-term comovement by using 3-year moving averages. In addition, they are careful with the issue of constant interest rates, because that does not necessarily mean monetary policy independence. ${ }^{7}$

This definition of monetary policy independence may be debated. It can be defined as the ${ }^{7}$ See the discussion by Aizenman et al. (2008). 
absence of correlation or a negative correlation if some similarities in these two countries' business cycles are included. However, an uncorrelated relationship between these two sets of interest rates provides an index equal to 0.5 . Because of this argument, I also employ the annual year interest rate differential à la Klein and Shambaugh (2015) as a robustness test. It sharply restricts endogeneity concerns, because this methodology differentiates between the evolution of domestic and base countries, the former as the dependent variable and the latter as the explanatory variable.

Furthermore, the comovement of interest rates may not be sufficient to reflect monetary policy autonomy, as suggested by Ricchi and Shi (2016). Rey (2016) points out that the global financial cycle could also affect house prices, credit, and mortgage spreads, which in turn affect the ability of the central bank to control the domestic economy. Popper et al. (2013), Rey (2016), and Ricchi and Shi (2016) build up credible alternatives, but the comovement of short-term interest rates matters when following Klein and Shambaugh (2015), Hofmann and Takàts (2015), and Han and Wei (2016). They add Taylor rules in their specifications to prove that interest rate differentials really mean autonomy. A country with a rapid GDP growth rate or rising inflation raises its policy interest rates. Klein and Shambaugh (2015) include domestic GDP growth and the inflation rate in their robustness checks, which does not change their results about the trilemma.

I account for the correlation of interest rates by controlling for the correlation of monthly consumer price indices between domestic country $i$ and base country $j$. It is the same methodology as Aizenman et al. (2008) and the index of inflation cycle desynchronization is defined as follows:

$$
\text { DesynchCPI } I_{i t}=1-\frac{\operatorname{corr}\left(C P I_{i m t}, C P I_{j m t}\right)+1}{2}
$$

As a consequence, this normalized index is equal to 1 if the two countries' inflation cycles reflect a perfect negative correlation. The statistics in Appendix 1 show that the mean and the volatility of this index are sufficiently relevant to warrant investigation. The comparison of 
these two indices of Figure 1 suggest a lagged correlation, probably due to inflation forecast changes or monetary policy effectiveness. This approach is in the same vein as Han and Wei (2016), but this concrete monthly data can be expected to provide additional information. For instance, the year 1986 reflects a high increase in inflation desynchronization and a drop in monetary policy independence in open economies. The disinflation policies were trending upwards with partial and heterogeneous results at the time. The decomposition of the inflation cycle according to open versus closed countries and advanced economies versus the developing world provides a similar trend in Figure A.2 in Appendix 2.

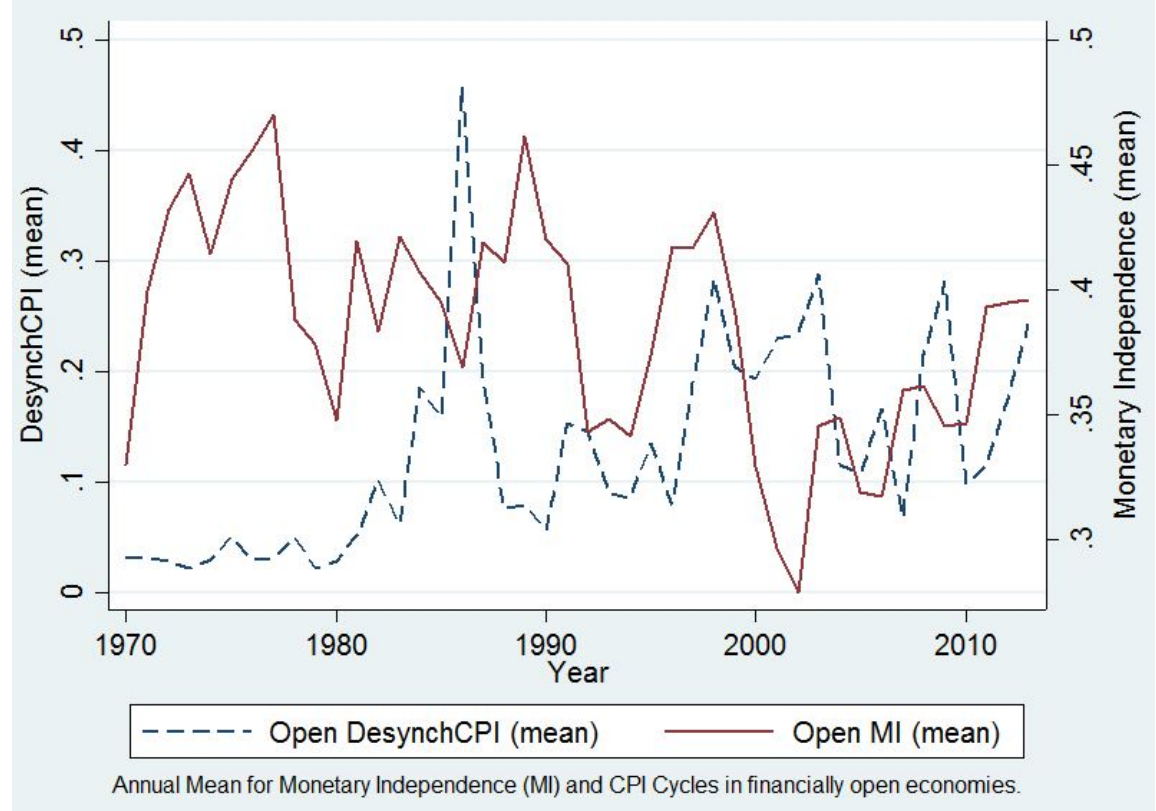

Figure 1 - Monetary Policy Independence and Inflation Cycle Desynchronization.

\subsection{Exchange-rate regime}

There are various exchange rate classifications. They differ because of methodologies, data sources, and objectives. Klein and Shambaugh (2006) discuss the strengths and weaknesses of each of them. Given that I test the trilemma, I focus on the de facto rather than de jure classification. In addition, the classification from Levy-Yeyati and Sturzenegger (2005) is irrelevant in this context, because it mixes monetary policy elements, nominal exchange rate, its volatility, and the volatility of international reserves. There is the same problem with the classification of Reinhart and Rogoff (2004). The comparison of dual and official exchange rate markets induces bias, but Passari and Rey (2015) use it to test the dilemma. I 
select various classifications because I use both continuous and binary indexes to ensure the reliability of the results.

First of all, the core classification comes from Klein and Shambaugh (2015). They use methodologies from Shambaugh (2004) and di Giovanni and Shambaugh (2008). This binary code Peg indicates 1 if the country is pegged and 0 if not. A peg is globally defined in a particular year if the bilateral exchange rate between the domestic and the base country stays in $\mathrm{a}+/-2 \%$ band over the course of that year. ${ }^{8}$ Moreover, I also use the Exchange Rate Stability continuous index from Aizenman et al. (2008) which follows the same idea as the monetary policy autonomy index. Their normalized index uses annual standard deviations of the monthly exchange rate between the domestic and the base country. Like the monetary index, Aizenman et al. (2008) do not apply it automatically. For instance, they consider the exchange rate as fixed if the annual variation in the bilateral exchange rate is higher than the +/ - 2 band in line with Klein and Shambaugh (2015). Over 45 percent (1,976 observations) reflect a peg in the binary classification from Klein and Shambaugh (2015), while over 35 percent $(1,551$ observations) of the sample is a peg with this continuous classification.

\subsection{Financial Openness}

Financial openness is naturally multi-dimensional. Some distinctions in these measures are potentially relevant: de jure or de facto measures, the differences between the extensity and intensity of capital controls, permanent or episodic controls, and targeted or not capital controls. The measure called Kaopen from Chinn and Ito (2006) is the best data source with respect to time and geographical coverage. ${ }^{9}$ It indicates a country's degree of capital account openness. It is based on the four binary dummy variables that codify the tabulation of restrictions on cross-border financial transactions reported in the Annual Report on Exchange Arrangements and Exchange Restrictions (AREAER) from the IMF. This measure is fairly

\footnotetext{
${ }^{8}$ Many improvements are feasible. For instance, di Giovanni and Shambaugh (2008) provide another dummy variable called Kspeg. Peg is a bit different from kspeg since the second one includes a single year peg but not discrete devaluations. In the same spirit, I could refer to the classification of intermediate exchange rate regime from Obstfeld et al. (2010) known as softpeg.

${ }^{9}$ See the survey of Quinn et al. (2011) and the comparison of measures by Forbes and Warnock (2012). About the de facto measure, the capital flows to GDP ratio à la Lane and Milesi-Ferretti (2007) is a good option, but it raises reverse causality issues.
} 
broad, because it takes into account current account and capital account transactions, the presence of multiple exchange rates, and the surrender of export proceeds. It does not take into account the intensity of capital controls such as Schindler (2009), but Chinn and Ito (2006) find a correlation of 83.9 percent between them. I build a binary index Open with this continuous Kaopen in order to to ensure the consistency of the results. I adopt the same conventional threshold in this literature which is 0.66 , following Goldberg (2013) and Klein and Shambaugh (2015).

Contrary to Klein and Shambaugh (2015), I have no particular need of a trimodal distribution, namely always open countries, always closed countries, and middle open countries. This third group is interestingly composed of the only countries that are sometimes open and sometimes closed. Yet, this distribution between "Open", "Gates," and "Walls" according to Klein (2012) provides some bias compared to continuous indices. A convincing recent database by Fernández et al. (2015) also distinguishes between capital controls on various kinds of capital flows, but it only covers the last twenty years.

\subsection{Other Control Variables}

Aizenman (2013) highlights the role of international reserves as a fourth corner, which in turn transforms the trilemma into a quadrilemma. Similarly, Popper et al. (2013) compare the stability of various configurations of the trilemma and corroborate the fact that large international reserves extend the trilemma. The data on international reserve holdings essentially comes from the World Bank and I exclude gold reserves. I compute a ratio with the GDP as is usual in this literature. The alternative would be a normalized index or a particular threshold to distinguish between high and low levels of international reserves. Aizenman and Ito (2012) find a 21\% GDP threshold level, while Klein and Shambaugh (2015) arbitrarily use a dummy if the level of international reserves is in the $75^{\text {th }}$ percentile of the distribution.

I control for the depth of the domestic financial system with two ratios of credit from the World Bank. The ratio used in the baseline specification reflects the depth of the banking sector and financial development in terms of size. It is straightforward that the independence 
of monetary policy strongly depends on the size of the financial sector and its linkages with the rest of the world. Yet, this measure does not highlight the heterogeneity across various economic agents. It only provides the global size of financial forces without saying anything about their nationality, their objectives, or their granularity. The second ratio corresponds to the domestic credit to the private sector, with obvious links with monetary policy autonomy. I investigate these two ratios with the presence of foreign lenders to clearly distinguish between national and international financial forces.

\subsection{Global Financial Cycle, Global Investors and Global Banks}

I am looking for the fluctuations and the exposure to this global financial cycle. Again, I employ both binary and continuous measures to ensure the reliability of the results. Appendix 3 highlights stylized facts about these various shifts and helps to justify the thresholds chosen.

Miranda-Agrippino and Rey (2015) and Rey (2015) demonstrate that the VIX is a good proxy for the whims of the global financial cycle. ${ }^{10}$ The VIX is the weighted average of the implied volatility of Standard and Poor's 500 index options and reflects a market estimate of future volatility. A VIX equal to 23 means that investors anticipate a feasible volatility in the next 3 months in the $+/-23 \%$ band. It reflects risk aversion and uncertainty in financial markets, and began in 1970 with the Bloom (2009) methodology. Because the VIX is daily data compared to the yearly time frequency used here, I can adopt the value at the end of the year, the annual mean, or the annual volatility. Figure A.3 in Appendix 3 sheds light on these measures. If I use the value at the end, this approach drops the highest (or smallest) value of the VIX or its standard deviation during a year. For instance, information about the volatility of the VIX during the year 1987 (Black Monday) or 1998 (Russian and Asian crises) would be lost. The year 1987 was stable with a relatively low VIX until October 1987, while the year 1998 featured strong volatility. I use the log of the annual mean of the VIX. In addition, the upward trend of the VIX with an increasing amplitude over time is in line with growing financial forces over time à la Rey (2015). This argument is similar to Borio (2014):

\footnotetext{
${ }^{10}$ Some papers try other variables such as the TED spread, the oil price, or the worldwide amount of domestic credit and cross-border credit, as I do in the robustness checks.
} 
the length and amplitude of the global financial cycle depends on policy regimes. Since I am looking for potential regime-switching dynamics, I also generate a dummy in order to capture the threshold value of the VIX that triggers the transmission channel. This dummy variable Stress is equal to 1 if the VIX is higher than its $75^{\text {th }}$ percentile of the distribution, that is 23. Partly for historical reasons and for the potential non-linear effect of the VIX, I employ this exogenous threshold in the baseline specification. First, a graphic analysis indicates that the dummy variable proxies the four periods of large financial instability in the last 40 years. Second, Nier et al. (2014) find that the VIX becomes the key driver of global financial flows if and only if the VIX is very high. Third, I consider the endogenous thresholds of the VIX by using a Panel Smoothing Transition Regression (PSTR) model in which the nature of the relationship between monetary independence and exchange rate regime/financial openness will depend on an endogenous threshold specific to a transition variable, namely the VIX. ${ }^{11}$ The Online Appendix provides close thresholds to the baseline.

Goldberg (2013) emphasizes the role of global banks in the transmission channel of the global financial cycle. Avdjiev et al. (2017) recently compared the impact of global financial conditions on cross-border loan flows and international debt securities. I investigate differences across countries in these two ways. All of the data come from the Bank for International Settlements (BIS).

First, I take into account the growing role of international debt securities. These debt securities on the money and bond markets are issued in a different country than the one where the borrower resides. Two variables are defined: the continuous ratio of international debt securities to GDP and also a binary version. There is a relatively weaker dataset for the continuous measure. It is explained by the short time coverage: it is impossible to be perfectly sure that this ratio is equal to zero when the BIS provides no data, but the role of global investors appears very weak at this time. ${ }^{12}$ I proceed in a similar manner as the VIX and this Global Investor dummy variable is equal to 1 if the ratio is higher than its $75^{\text {th }}$ percentile of

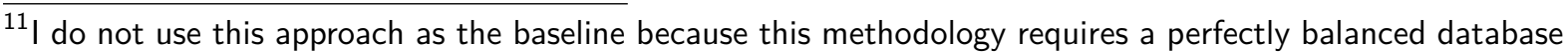
and would sharply restrict the sample to 50 countries when focusing on the VIX.

${ }^{12}$ In the database, the BIS data never begins with a high amount of international debt securities, which supports my assumption.
} 
the distribution, that is $15 \%$ of the GDP. This threshold is not estimated but it appears sufficiently high in order to capture potential non-linearities. Figure A.4 in Appendix 3 illustrates this idea: there is almost no country in the 1970s and in the 1980s where the presence of global investors exceeds the threshold. I will ensure the consistency of the approach through various tests. ${ }^{13}$

Second, I follow Goldberg (2013) and Avdjiev et al. (2017), and use BIS International Banking Statistics (IBS). They provide two datasets, the Locational and Consolidated Banking Statistics. The first can help to prevent financial vulnerabilities à la Bruno and Shin (2015b), while the second is designed to assess the dependence of individual borrowing countries on foreign bank creditors. Consequently, I use the consolidated foreign claims of reporting banks on individual countries that correspond to the effective role of global banks in the domestic financial system. This variable is computed on an immediate counterparty basis and not on an ultimate risk basis, which is more relevant to capture adverse liquidity shock transmission, as the BIS suggests. Contrary to Goldberg (2013) who uses the share of foreign claims on local residents relative to domestic credit volumes, I consider this volume relative to the GDP in order to keep all the possible effects in the economy. ${ }^{14}$ Again, both continuous and dummy variables are defined. The dummy variable called Global Bank is built with the $75^{\text {th }}$ percentile of the distribution, that is $35 \%$ of the GDP. It follows the same rule of selection for easier comparison and will use similar tests as used for global investors. Figure A.5 in Appendix 3 calls for this specification with only offshore financial center countries that are five times above the threshold. Nevertheless, I must caution that the global investors' data generally begins at the beginning of their presence in the country, while the data on global banks begins in 1983 in the best case. I assume that these foreign claims are low when the BIS does not provide information, given the historical trend and the earliest data provided. ${ }^{15}$

\footnotetext{
${ }^{13}$ The Online Appendix tests various thresholds and makes sure that the results are not driven by outliers.

${ }^{14}$ The level of credit relative to the GDP is an excellent early warning indicator of financial crises and probably better than credit growth. See Schularick and Taylor (2012) and Mendoza and Terrones (2008).

${ }^{15}$ This methodology is employed if and only if there is no reasonable doubt. The earliest values for each country are low. In other countries, it is hard to tell whether the presence of global banks is always low or high, or when a shift appears before 1983. Thus, I restrict the database for these cases. The list of these countries beginning in 1983 with a relatively high presence of global banks is as follows: the Bahamas, Bahrain, Brazil, Chile, Costa Rica, Ivory Coast, Jamaica, Kuwait, Korea, Malaysia, Mexico, Peru, the Philippines, Portugal, and Uruguay. I test this assumption in Online Appendix.
} 


\subsection{Stylized Facts}

Table 1 - Exchange Rate and Financial Openness Regime Shifts

\begin{tabular}{|c|c|c|c|c|c|c|c|c|}
\hline \multirow[b]{2}{*}{ Shift to } & \multirow[b]{2}{*}{ Conditional on } & \multirow[b]{2}{*}{ All } & \multicolumn{2}{|c|}{ Financial Stress } & \multicolumn{2}{|c|}{$\begin{array}{l}\text { High presence of } \\
\text { Global Investors }\end{array}$} & \multicolumn{2}{|c|}{$\begin{array}{l}\text { High presence of } \\
\text { Global Banks }\end{array}$} \\
\hline & & & Yes & No & Yes & No & Yes & No \\
\hline \multicolumn{9}{|c|}{ Exchange-Rate Regime Shift } \\
\hline Float $\rightarrow$ Peg & Closed & 108 & 36 & 72 & 6 & 102 & 9 & 99 \\
\hline Peg $\rightarrow$ Float & Closed & 121 & 37 & 84 & 6 & 115 & 5 & 116 \\
\hline Float $\rightarrow$ Peg & Open & 43 & 13 & 30 & 7 & 36 & 12 & 31 \\
\hline Peg $\rightarrow$ Float & Open & 32 & 11 & 21 & 3 & 29 & 8 & 24 \\
\hline \multicolumn{9}{|c|}{ Financial Openess Regime Shift } \\
\hline Closed $\rightarrow$ Open & Float & 54 & 25 & 29 & 7 & 47 & 7 & 47 \\
\hline Open $\rightarrow$ Closed & Float & 20 & 11 & 9 & 1 & 19 & 3 & 17 \\
\hline Closed $\rightarrow$ Open & Fixed & 17 & 5 & 12 & 2 & 15 & 4 & 13 \\
\hline Open $\rightarrow$ Closed & Fixed & 8 & 3 & 5 & 1 & 7 & 1 & 7 \\
\hline Total & & 403 & $\begin{array}{l}141 \\
35 \%\end{array}$ & $\begin{array}{l}262 \\
65 \%\end{array}$ & $\begin{array}{c}33 \\
8,2 \%\end{array}$ & $\begin{array}{c}370 \\
91,8 \%\end{array}$ & $\begin{array}{c}49 \\
12,2 \%\end{array}$ & $\begin{array}{c}354 \\
87,8 \%\end{array}$ \\
\hline
\end{tabular}

The statistics in Table 1 show the various shifts in financial openness and the exchange rate regime over time. It describes in detail the decomposition of conditional shifts according to the state of the global financial cycle and the presence of global investors and global banks. Over 75 percent (304) of these observations represent a shift in the exchange rate regime, but there is no clear trend in favor of a fixed or floating exchange rate. The dynamic of financial liberalization is more certain and a trimodal decomposition is feasible, consistent with Klein (2012). Some countries are (or have become) ${ }^{16}$ persistently open, others are persistently closed (Walls), and the rest do not follow a simple trend of financial liberalization (Gates). Out of the total $74(54+17)$ observations of shifts to financial openness, 41 reflect the sole shift for the country over the existing time coverage to permanent financial liberalization. ${ }^{17}$ In addition, the relatively small number of shifts $(43+17)$ which leads to the open peg configuration illustrates the strength of these trilemma trade-offs.

Table 1 also reports the number of shifts according to the exposure of the global financial cycle. This classification puts just over one-third (35\%) of these shifts in a high global

\footnotetext{
${ }^{16}$ The classification of Klein (2012) is based on a 1995 to 2011 dataset. Some countries that Klein codifies as persistently open for this period may have become open in my time coverage or before.

${ }^{17}$ Germany, Sweden, Hong Kong, Panama, Kuwait, and Saudi Arabia have been perfectly open since 1970 or before. Consequently, they are not reported in these observations of shifts.
} 
financial cycle. Perhaps surprisingly, there is no clear movement to a flexible exchange rate or to financial international restrictions in these stress times and vice versa in normal times. The presence of global investors and global banks are the most discriminative with only $8.2 \%$ and $12.2 \%$ of the shifts, respectively. On the one hand, the potential statistical significance of the presence of global players could not be driven by a large number of shifts. On the other hand, it could be biased by the relative importance of one country in these specific variables, but they reflect various years and various countries, both advanced and emerging in almost all cases.

To ensure the link with monetary policy independence, I analyze the possible comovement between the monetary policy independence de facto index, the VIX, and the presence of global players in domestic economies. Figure A.6 in Appendix 3 suggests that the global financial cycle could play a role in the trilemma at least through global banks. At first sight, the negative comovement seems to appear, especially for the VIX and the high presence of global banks in domestic economies. But this worldwide index of monetary policy independence is also driven by general trends in terms of financial openness, degree of fixity of the exchange rate, and the level of international reserves. In addition, the global financial cycle is a recent phenomenon, especially in emerging and developing countries.

\section{Results}

\subsection{Identification Strategy}

The empirical setting used is close to the one proposed by Goldberg (2013) and Obstfeld (2015), but with the comovement of the policy interest rate as the dependent variable and other new control variables. I consider a measure of monetary policy independence $M I_{i t}$ with the following specification:

$$
\begin{aligned}
M I_{i t}= & \beta_{0}+\beta_{1} \text { Peg_Open }_{i t}+\beta_{2} \text { Peg_Closed }_{i t}+\beta_{3} \text { Open_Peg }_{i t}+\beta_{4} \text { Open_Float }_{i t} \\
& +\beta_{5}^{\prime} X_{i t}+\beta_{6}^{\prime} \Theta_{i t}+\mu_{i}+\lambda_{t}+\epsilon_{i t}
\end{aligned}
$$


where $\mu_{i}$ is the country fixed effect and $\lambda_{t}$ the year fixed effect. $X_{i t}$ is a vector of control variables, that is the ratio of international reserves to GDP, the depth of the domestic financial system, and the index of inflation desynchronization. $\Theta_{i t}$ is a vector of two binary variables, Global Investors and Global Banks, which reflect the degree of international financial linkages across time and countries. The first four variables about trilemma configurations are conditional terms: ${ }^{18}$ with the following specification, Peg_Open $n_{i t}$ means for instance a shift in period $t$ from float to peg given that the country is open in periods $t-1$ and $t$.

The comparison of these coefficients allows me to refine the trilemma analysis in line with Han and Wei (2016). $\left(\beta_{1}, \beta_{2}\right)$ investigate the potential effective role of the exchange rate regime, whereas $\left(\beta_{3}, \beta_{4}\right)$ consider capital flow management policies. International financial forces should make the monetary policy independence index drop, especially for open countries, with $\left|\beta_{1}\right|>\left|\beta_{2}\right|$. The results should be consistent with the trilemma story with a negative effect of a fixed exchange rate and financial openness, so that $\left(\beta_{1}, \beta_{3}\right)$ should be significantly smaller than $\left(\beta_{2}, \beta_{4}\right)$. Indeed, coefficients $\beta_{1}$ and $\beta_{3}$ reflect the impossible case of the trilemma, i.e. a financially open country with pegged exchange rate. Moreover, the potential difference between these two coefficients can provide new information: $\left|\beta_{1}\right|>\left|\beta_{3}\right|$ implies that the fixity of the exchange rate regime is the key ingredient in the transmission and amplification of the trilemma. By contrast, if $\left|\beta_{1}\right|<\left|\beta_{3}\right|$, the openness to international financial forces is the triggering factor of all amplification mechanisms.

A first test of this trilemma-dilemma debate is analyzing the potential stability of coefficients $\beta_{1}, \beta_{2}, \beta_{3}$, and $\beta_{4}$ when successively including the variables of the global financial cycle, that is the high presence of global investors, global banks, and the high level of the VIX. If the dilemma is true, the global financial cycle should deepen the effect of financial openness and sharply reduce the effect of the exchange rate regime. In absolute terms, there may even be higher coefficients $\beta_{3}$ and $\beta_{4}$, while $\beta_{1}$ should be reduced in times of high global financial

\footnotetext{
${ }^{18}$ This approach gives the same results as simple terms Peg, Open and the interact term. It may also generate more multicollinearity problems. By using this alternative specification in the Online Appendix, I ensure that the results are consistent with a potential multicollinearity bias. Finally, the baseline specification with conditional terms is preferable for the sake of space, and answer the timing question of trilemma mechanisms. Indeed, the interaction term should represent three possible cases, which are a shift from closed peg to open peg, a shift from open float to open peg, or a simultaneous shift from closed float to open peg.
} 
cycle.

As a second test, I also interact trilemma and global financial cycle variables. These interaction terms will make it possible to identify the key transmission channel of this global financial cycle and to provide a new argument in this possible shift from trilemma to dilemma. If the trilemma morphs into a dilemma, the interaction terms with a high presence of global players should magnify the effect of financial openness on monetary policy independence and, at the same time, reduce the effect of a pegged exchange rate. Yet, if Obstfeld (2015) is right, the global financial cycle has amplification effects for both, including the fixity of the exchange rate regime. I employ a similar methodology to assess the role of the fluctuation of this global financial cycle by using interaction terms with a high level of VIX. It tests the hypothesis that the dilemma is relevant only for a high level of financial stress. Nevertheless, the year fixed effects should be dropped in this specific test because the VIX only varies over time by definition and is captured by year fixed effects.

Obstfeld (2015) discusses the puzzling implications of fixed effects. He notably compares estimates with year fixed effects and with the VIX. Yet, this approach with the VIX is contingent on missing explanatory variables and the coverage of the sample, following Hofmann and Takàts (2015). The comparison of estimates is sensitive if differences remain. By contrast, I propose a two-step methodology by treating the estimated year fixed effect from equation (3) as a dependent variable in this following equation:

$$
\widehat{\lambda_{t}}=\alpha V I X_{t}+\zeta_{i t}
$$

Coefficient $\alpha$ catches part of the year fixed effect explained by the VIX and the $R^{2}$ of equation (4) determine the extent to which this proxy of the global financial cycle could be compared to other specifications à la Obstfeld (2015). This does not require a specific methodology because the coefficients obtained from this specification with the estimated dependent variable are unbiased. As a robustness check, I also include other similar global variables traditionally used in the literature. 
The empirical setting does not allow to say whether the impact of trilemma policy decisions is not only in the short term but also in the long term. However, the period $i$ of the trilemma policy decision may be different from the period $j$ of a move in the fluctuation or in the domestic exposure to the global financial cycle. The interaction terms include and differentiate these two types of shocks. For instance, if I suppose that a policy decision is taken at least one year before a move to a high global financial cycle $(i<j)$, the coefficient of the policy decision corresponds to the first effect and the interaction term reflects the magnification effect.

My strategy with the comovement of interest rates and successive fixed effects minimizes the risk of collinearity as another benefit. Klein and Shambaugh (2015) generally do not use fixed effects because their dependent variable is the first difference of the domestic interest rate and the first difference of the base country interest as one of their control variables. First, the inclusion of country fixed effects in their case only catches countries that constantly raise or lower their interest rates. By contrast, the probability that a correlation of monthly interest rates will always follow the same trend is reduced. Second, Klein and Shambaugh (2015) fear collinearity and do not use year fixed effects because of the correlation across base countries' interest rates. I expect the risk of collinearity to be lower because the correlation with monthly interest rates should be more informative.

I explore endogeneity concerns in a next step. The recent literature such as Aizenman et al. (2016) generally uses lagged values to minimize risks of potential reverse causality. The methodology of Klein and Shambaugh (2015) with this different dependent variable and the use of subsamples appears more robust to this potential endogeneity bias. All of these treatments will be used as robustness tests.

\subsection{Baseline Results: Trilemma Mechanisms}

Table 2 reports the baseline specification with successive fixed effects. It allow alleviating some problems. Column (1) first presents a pooled OLS specification without any fixed effects and I successively add country and year fixed effects to disentangle the various determinants of 
the trilemma. Without any fixed effects, the three coefficients of the trilemma cases speak for long-term coefficients. They compare pegged to not pegged countries, and open to closed countries respectively. The specification in column (2) is close to a within-estimator with country fixed effects. The inclusion of year fixed effects in other columns takes into account the waves in the co-evolution of financial openness and exchange rate regimes over time, which in turn could generate a downward bias in the estimation of policy choices. It could be interpreted as evidence that policy choices about the exchange rate are strongly dependent on the degree of financial openness and vice versa.

Monetary independence is mainly driven by financial openness and the exchange rate regime. The policy options corresponding to the worst trilemma case sharply reduce monetary policy autonomy. This may set off an amplification of international financial pressures, according to Obstfeld et al. (2005), Aizenman et al. (2008), and Han and Wei (2016). When including country fixed effects in columns (2) and (3), the shift from float to peg diminishes the degree of monetary policy autonomy if and only if the country is financially open. By comparison, the move from closed to open reduces monetary policy independence, whatever the exchange rate regime in column (2). These sensitivities are always ranked in the same order: the shift to peg for open countries and the shift to open for peg countries sharply reduce monetary policy autonomy, while the shift to peg for closed countries and the shift to open for float countries have no or small effect. The comparison of $\beta_{1}$ and $\beta_{3}$ does not point at a conclusive impact of timing in terms of trilemma policies. Going into more detail, the policy decision for one country to move towards this worst trilemma configuration, i.e. financially open with pegged exchange rate, is associated with a significant 0.08 point decrease in the normalized monetary policy autonomy index. By contrast, Han and Wei (2016) find a similar ranking of coefficients over the past decade, but not for the nineties, while I employ a longer time coverage and control for country and year fixed effects.

The comparison of columns (2) and (3) does not allow to say whether the effect of financial openness only exists when the country follows a peg, but the effect is always quantitatively higher for peg than float. The puzzling differences with or without year fixed effects are 
probably due to the explanatory power of the VIX and thus its inability to capture all common trends. This could also be explained by the non-linear effect of the VIX in the economy, in line with Nier et al. (2014), and by the choice of the time coverage (Hofmann and Takàts (2015)): the global financial cycle and the VIX as its proxy are relatively recent growing trends according to the long time coverage used. Nevertheless, the two-step approach provides a way to quantify the effect of the VIX. This proxy of the global financial cycle explains around $20-30 \%$ of the year fixed effects, according to my specification. It is negatively correlated with the estimated year fixed effects, which in turn suggest that high risk aversion and uncertainty generate a large global drop in monetary policy independence. Consequently, the VIX is a main driver of worldwide monetary policy independence with a global compression mechanism of interest rates.

Table 2 also reveals that the depth of the domestic financial system is negatively correlated with monetary policy independence. Two complementary explanations are conceivable. On the one hand, this could reflect the trade-off between macroeconomic stabilization and financial stability, which can be affected by the global financial cycle. On the other hand, Schularick and Taylor (2012) demonstrate that the credit ratio is a very good predictor of financial crises. By extrapolation, these financial forces could magnify vulnerability and require a policy intervention. The role of international reserves supports the idea of a quadrilemma, following Aizenman (2013). Besides, the desynchronization of inflation cycles has no real impact, implying that the correlation of policy interest rates is a good measure of monetary policy independence.

Finally, I include dummy variables that reflect the presence of global investors and global banks. Their high presence sharply reduces monetary policy independence: it is associated with a drop of 0.04 points in the normalized index. The quantitative effect is similar for both players, and maybe more importantly, this result remains almost identical in columns (6) when investigating the two players at the same time. Goldberg (2013) points out their role in international shock transmission and business cycle comovements through the reduction of financial and informational frictions. She also highlights the various roles of these bank 
affiliates, entailing heterogeneity in the shock transmission. This could also be explained by the risk-taking channel from Bruno and Shin (2015a). The level of international reserves plays a role only for columns (3) and (4), but not anymore with the high presence of global banks. Indeed, central banks hold international reserves to protect the domestic financial system against currency and banking twin crises in the spirit of Obstfeld et al. (2010). Another consequence of this presence of global players is the change in the coefficient in the secondstage estimation: the VIX loses a part of its statistical power, because it is correlated with the high presence of global players, especially global investors.

\subsection{Looking for the Role of Global Players}

Tables 3 and 4 highlight the effects of these conditional terms according to the domestic presence of global investors and global banks. I interact these 4 cases with dummies representing the relative importance of global investors and global banks, respectively. First of all, these trilemma shifts with any global players are consistent with the previous table. The sensitivities follow the same ranking, and the changes across columns are explained by the successive interaction terms. The set of control variables provides similar results as in Table 2 with negative and statistically significant effects of the national and international financial systems through the size of the domestic financial system and the VIX. The inclusion of global investors in Table 3 reduces the leading role of the VIX, whereas the inclusion of global banks in Table 4 does not aim to compete with the power of the fluctuations of the global financial cycle.

The presence of global investors per se generally affects monetary policy independence according to Table 3. When the money and bond markets clearly depend on global investors, the two shifts corresponding to the worst case in trilemma configurations have strong effects on the Central Bank's ability to implement its own monetary policy. Therefore, it can be concluded here that the high presence of global investors on the money and bond domestic markets worsens trilemma trade-offs. When a country goes to the worst configuration, financial forces cut monetary policy independence by around 0.07 point without global investors, and cut by 0.13 point with these global investors. This is an amplification effect which almost 
Table 2 - Baseline Specification - Trilemma Mechanisms

\begin{tabular}{|c|c|c|c|c|c|c|}
\hline \multirow[b]{2}{*}{ Dep. Var. } & $(1)$ & $(2)$ & 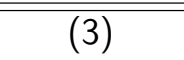 & 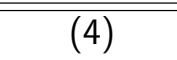 & 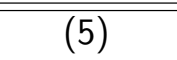 & 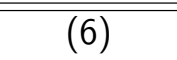 \\
\hline & \multicolumn{6}{|c|}{ Monetary Policy Independence Index } \\
\hline Peg_Open & $\begin{array}{c}-0.0981^{* * *} \\
(0.0208)\end{array}$ & $\begin{array}{c}-0.0890^{* * *} \\
(0.0210)\end{array}$ & $\begin{array}{c}-0.0843^{* * *} \\
(0.0214)\end{array}$ & $\begin{array}{c}-0.0788^{* * *} \\
(0.0216)\end{array}$ & $\begin{array}{c}-0.0786^{* * *} \\
(0.0218)\end{array}$ & $\begin{array}{c}-0.0746^{* * *} \\
(0.0219)\end{array}$ \\
\hline Peg_Closed & $\begin{array}{c}-0.0382^{* * *} \\
(0.0121)\end{array}$ & $\begin{array}{c}-0.0105 \\
(0.00993)\end{array}$ & $\begin{array}{l}-0.00959 \\
(0.0102)\end{array}$ & $\begin{array}{l}-0.00737 \\
(0.0103)\end{array}$ & $\begin{array}{l}-0.00773 \\
(0.0102)\end{array}$ & $\begin{array}{l}-0.00603 \\
(0.0103)\end{array}$ \\
\hline Open_Peg & $\begin{array}{c}-0.117^{* * *} \\
(0.0218)\end{array}$ & $\begin{array}{c}-0.0980^{* * *} \\
(0.0231)\end{array}$ & $\begin{array}{c}-0.0934^{* * *} \\
(0.0218)\end{array}$ & $\begin{array}{c}-0.0849^{* * *} \\
(0.0212)\end{array}$ & $\begin{array}{c}-0.0873^{* * *} \\
(0.0209)\end{array}$ & $\begin{array}{c}-0.0807^{* * *} \\
(0.0205)\end{array}$ \\
\hline Open_Float & $\begin{array}{l}-0.0188 \\
(0.0135)\end{array}$ & $\begin{array}{l}-0.0228^{*} \\
(0.0127)\end{array}$ & $\begin{array}{l}-0.00870 \\
(0.0134)\end{array}$ & $\begin{array}{l}-0.00319 \\
(0.0136)\end{array}$ & $\begin{array}{l}-0.00799 \\
(0.0136)\end{array}$ & $\begin{array}{r}-0.00325 \\
(0.0137)\end{array}$ \\
\hline Int. Res. & $\begin{array}{c}0.0663 \\
(0.0418)\end{array}$ & $\begin{array}{c}0.0672 \\
(0.0498)\end{array}$ & $\begin{array}{l}0.0933^{*} \\
(0.0552)\end{array}$ & $\begin{array}{l}0.0956^{*} \\
(0.0569)\end{array}$ & $\begin{array}{c}0.0782 \\
(0.0544)\end{array}$ & $\begin{array}{c}0.0822 \\
(0.0563)\end{array}$ \\
\hline Dom. Fin. & $\begin{array}{c}-0.0630^{* * *} \\
(0.0145)\end{array}$ & $\begin{array}{c}-0.0804^{* * *} \\
(0.0154)\end{array}$ & $\begin{array}{c}-0.0690^{* * *} \\
(0.0179)\end{array}$ & $\begin{array}{c}-0.0581^{* * *} \\
(0.0175)\end{array}$ & $\begin{array}{c}-0.0527^{* * *} \\
(0.0174)\end{array}$ & $\begin{array}{c}-0.0452^{* * *} \\
(0.0171)\end{array}$ \\
\hline DesynchCPI & $\begin{array}{l}-0.00809 \\
(0.0170)\end{array}$ & $\begin{array}{l}-0.0220^{*} \\
(0.0118)\end{array}$ & $\begin{array}{l}-0.0101 \\
(0.0123)\end{array}$ & $\begin{array}{l}-0.00987 \\
(0.0125)\end{array}$ & $\begin{array}{l}-0.0115 \\
(0.0124)\end{array}$ & $\begin{array}{l}-0.0112 \\
(0.0126)\end{array}$ \\
\hline VIX (log) & $\begin{array}{l}0.000867 \\
(0.0104)\end{array}$ & $\begin{array}{l}-0.00207 \\
(0.00995)\end{array}$ & & & & \\
\hline Global Investors & & & & $\begin{array}{c}-0.0557^{* * *} \\
(0.0151)\end{array}$ & & $\begin{array}{c}-0.0490^{* * *} \\
(0.0148)\end{array}$ \\
\hline Global Banks & & & & & $\begin{array}{c}-0.0493^{* * *} \\
(0.0127)\end{array}$ & $\begin{array}{c}-0.0427^{* * *} \\
(0.0126)\end{array}$ \\
\hline Cons & $\begin{array}{l}0.503^{* * *} \\
(0.0327)\end{array}$ & $\begin{array}{l}0.513^{* * *} \\
(0.0325)\end{array}$ & $\begin{array}{l}0.518^{* * *} \\
(0.0165)\end{array}$ & $\begin{array}{l}0.508^{* * *} \\
(0.0172)\end{array}$ & $\begin{array}{l}0.516^{* * *} \\
(0.0166)\end{array}$ & $\begin{array}{l}0.508^{* * *} \\
(0.0174)\end{array}$ \\
\hline Country FE & No & Yes & Yes & Yes & Yes & Yes \\
\hline Year FE & No & No & Yes & Yes & Yes & Yes \\
\hline $\begin{array}{l}\text { P-value } \beta_{1}=\beta_{3} \\
\text { Second-stage }\end{array}$ & 0.612 & 0.808 & 0.803 & 0.867 & 0.810 & 0.865 \\
\hline VIX $(\log )$ & & & $-0.0078^{* * *}$ & $-0.005^{* * *}$ & $-0.0071^{* * *}$ & $-0.0053^{* * *}$ \\
\hline$\%$ of Year FE & & & 0.307 & 0.195 & 0.285 & 0.183 \\
\hline Obs. & 4427 & 4427 & 4427 & 4427 & 4427 & 4427 \\
\hline Countries & 161 & 161 & 161 & 161 & 161 & 161 \\
\hline $\operatorname{adj} . R^{2}$ & 0.202 & 0.111 & 0.150 & 0.157 & 0.156 & 0.162 \\
\hline
\end{tabular}

With the within estimator, Peg_Open means a shift from float to peg given that a country is open.

With the within estimator, Open_Peg means a shift from closed to open given that a country is pegged.

${ }^{*},{ }^{* *}$, and ${ }^{* * *}$ respectively denote significance at the 10,5 , and $1 \%$ levels.

Standard errors in parentheses.

doubles the initial forces. However, the comparison between on the one hand columns (3) and (6) and on the other hand column (7) suggests multicollinearity, which in turn affects the quantitative results. There is probably not enough information in the data to estimate the 
model accurately. The use of dummy variables is one plausible explanation, but the results are consistent in the first six columns. Another consequence of multicollinearity is the over- and underestimation of the correlated coefficients. This could explain why the impact of global investors per se does not seem robust when using multiple interaction terms in columns (6) and (7).

In contrast to global investors, the presence of global banks per se seems to have no impact on monetary policy autonomy contrary to Table 2, suggesting that global banks worsen the trilemma in some specific trilemma configurations. The move to peg for open countries has greater consequences with global banks, while the trilemma is the same for closed countries following a similar shift. Potential international financial pressures from specific exchange rate regimes do not increase with specific capital controls and prudential regulation. Column (2) suggests that the high presence of global banks could even reduce the drop in monetary policy independence for a closed country following this exchange rate regime shift. Yet, this effect is statistically significant only at $10 \%$ and it disappears in column (3). By comparison, the decision to open current and capital accounts when a large part of claims comes from global banks sharply restricts monetary policy independence in columns (4) and (6). The comparison between columns (5), (6), and (7) raises questions about their hypothetical role for a shift to open for pegged countries. It brings to the worst configuration and the domestic country should feel the full brunt of the global financial cycle, but it becomes statistically insignificant. The small number of these particular policy decisions also supports the idea of multicollinearity. With this assumption, the interaction terms with global investors could be considered as a placebo test to ensure the consistency of the results. As a consequence, the high presence of global banks lifts the drop in monetary policy independence in three policy shifts. The shift from closed float to open float leads to a decrease of 0.06 point in the normalized index without a high presence of global banks. With these players, it seems that the effect has more more than doubled. The shift from open float to open peg leads to a similar drop of 0.15 points in the high presence of these global banks, and 0.05 points if not. I also investigate the use of global investors and global banks at the same time. These results are not reported for the sake of concision, but all previous results are consistent. 
Table 3 - Looking for the Role of Global Investors

\begin{tabular}{|c|c|c|c|c|c|c|c|}
\hline \multirow[b]{2}{*}{ Dep. Var. } & $\overline{(1)}$ & $\overline{(2)}$ & $\overline{(3)}$ & $\overline{~(4)}$ & 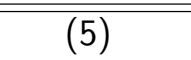 & $\overline{~(6)}$ & $\overline{(7)}$ \\
\hline & \multicolumn{7}{|c|}{ Monetary Policy Independence Index } \\
\hline Peg_Open & $\begin{array}{c}-0.0648^{* * *} \\
(0.0225)\end{array}$ & $\begin{array}{c}-0.0773^{* * *} \\
(0.0217)\end{array}$ & $\begin{array}{c}-0.0649^{* * *} \\
(0.0226)\end{array}$ & $\begin{array}{c}-0.0737^{* * *} \\
(0.0215)\end{array}$ & $\begin{array}{c}-0.0766^{* * *} \\
(0.0214)\end{array}$ & $\begin{array}{c}-0.0736^{* * *} \\
(0.0214)\end{array}$ & $\begin{array}{c}-0.0676^{* * *} \\
(0.0228)\end{array}$ \\
\hline Peg_Closed & $\begin{array}{r}-0.00796 \\
(0.0102)\end{array}$ & $\begin{array}{l}-0.00967 \\
(0.0105)\end{array}$ & $\begin{array}{l}-0.00887 \\
(0.0104)\end{array}$ & $\begin{array}{l}-0.00788 \\
(0.0102)\end{array}$ & $\begin{array}{r}-0.00730 \\
(0.0103)\end{array}$ & $\begin{array}{l}-0.00784 \\
(0.0102)\end{array}$ & $\begin{array}{l}-0.00923 \\
(0.0104)\end{array}$ \\
\hline Open_Peg & $\begin{array}{c}-0.0764^{* * *} \\
(0.0206)\end{array}$ & $\begin{array}{c}-0.0832^{* * *} \\
(0.0211)\end{array}$ & $\begin{array}{c}-0.0762^{* * *} \\
(0.0206)\end{array}$ & $\begin{array}{c}-0.0676^{* * *} \\
(0.0219)\end{array}$ & $\begin{array}{c}-0.0825^{* * *} \\
(0.0213)\end{array}$ & $\begin{array}{c}-0.0681^{* * *} \\
(0.0218)\end{array}$ & $\begin{array}{c}-0.0737^{* * *} \\
(0.0229)\end{array}$ \\
\hline Open_Float & $\begin{array}{r}-0.00586 \\
(0.0133)\end{array}$ & $\begin{array}{l}-0.00170 \\
(0.0136)\end{array}$ & $\begin{array}{l}-0.00511 \\
(0.0132)\end{array}$ & $\begin{array}{l}-0.00561 \\
(0.0133)\end{array}$ & $\begin{array}{l}-0.0102 \\
(0.0138)\end{array}$ & $\begin{array}{l}-0.00656 \\
(0.0138)\end{array}$ & $\begin{array}{l}-0.00700 \\
(0.0139)\end{array}$ \\
\hline Int. Res. & $\begin{array}{c}0.0937 \\
(0.0585)\end{array}$ & $\begin{array}{l}0.0970^{*} \\
(0.0571)\end{array}$ & $\begin{array}{c}0.0944 \\
(0.0586)\end{array}$ & $\begin{array}{c}0.0942 \\
(0.0586)\end{array}$ & $\begin{array}{c}0.0945 \\
(0.0575)\end{array}$ & $\begin{array}{c}0.0941 \\
(0.0586)\end{array}$ & $\begin{array}{c}0.0946 \\
(0.0586)\end{array}$ \\
\hline Dom. Fin. & $\begin{array}{c}-0.0556^{* * *} \\
(0.0172)\end{array}$ & $\begin{array}{c}-0.0567^{* * *} \\
(0.0175)\end{array}$ & $\begin{array}{c}-0.0552^{* * *} \\
(0.0172)\end{array}$ & $\begin{array}{c}-0.0554^{* * *} \\
(0.0172)\end{array}$ & $\begin{array}{c}-0.0587^{* * *} \\
(0.0172)\end{array}$ & $\begin{array}{c}-0.0556^{* * *} \\
(0.0174)\end{array}$ & $\begin{array}{c}-0.0554^{* * *} \\
(0.0174)\end{array}$ \\
\hline DesynchCPI & $\begin{array}{r}-0.00843 \\
(0.0128)\end{array}$ & $\begin{array}{l}-0.00928 \\
(0.0128)\end{array}$ & $\begin{array}{l}-0.00827 \\
(0.0129)\end{array}$ & $\begin{array}{l}-0.00858 \\
(0.0127)\end{array}$ & $\begin{array}{r}-0.00987 \\
(0.0125)\end{array}$ & $\begin{array}{c}-0.00864 \\
(0.0127)\end{array}$ & $\begin{array}{l}-0.00835 \\
(0.0128)\end{array}$ \\
\hline Global Investor & $\begin{array}{c}-0.0343^{* *} \\
(0.0170)\end{array}$ & $\begin{array}{c}-0.0613^{* * *} \\
(0.0159)\end{array}$ & $\begin{array}{c}-0.0377^{* *} \\
(0.0181)\end{array}$ & $\begin{array}{c}-0.0351^{* *} \\
(0.0166)\end{array}$ & $\begin{array}{c}-0.0685^{* * *} \\
(0.0187)\end{array}$ & $\begin{array}{c}-0.0379 \\
(0.0240)\end{array}$ & $\begin{array}{l}-0.0462 \\
(0.0305)\end{array}$ \\
\hline Peg_Open x Globallnv & $\begin{array}{c}-0.0650^{* *} \\
(0.0308)\end{array}$ & & $\begin{array}{c}-0.0616^{* *} \\
(0.0311)\end{array}$ & & & & $\begin{array}{l}-0.0376 \\
(0.0486)\end{array}$ \\
\hline Peg_Closed x Globallnv & & $\begin{array}{c}0.0391 \\
(0.0351)\end{array}$ & $\begin{array}{c}0.0160 \\
(0.0354)\end{array}$ & & & & $\begin{array}{c}0.0241 \\
(0.0395)\end{array}$ \\
\hline Open_Peg x Globallnv & & & & $\begin{array}{c}-0.0643^{* *} \\
(0.0302)\end{array}$ & & $\begin{array}{l}-0.0614^{*} \\
(0.0353)\end{array}$ & $\begin{array}{l}-0.0161 \\
(0.0406)\end{array}$ \\
\hline Open_Float x Globallnv & & & & & $\begin{array}{c}0.0338 \\
(0.0251)\end{array}$ & $\begin{array}{l}0.00511 \\
(0.0285)\end{array}$ & $\begin{array}{c}0.0124 \\
(0.0334)\end{array}$ \\
\hline Cons & $\begin{array}{l}0.506^{* * *} \\
(0.0174)\end{array}$ & $\begin{array}{l}0.508^{* * *} \\
(0.0173)\end{array}$ & $\begin{array}{l}0.506^{* * *} \\
(0.0174)\end{array}$ & $\begin{array}{l}0.506^{* * *} \\
(0.0174)\end{array}$ & $\begin{array}{l}0.509^{* * *} \\
(0.0172)\end{array}$ & $\begin{array}{l}0.507^{* * *} \\
(0.0174)\end{array}$ & $\begin{array}{l}0.507^{* * *} \\
(0.0175)\end{array}$ \\
\hline $\begin{array}{l}\text { Country FE } \\
\text { Year FE }\end{array}$ & $\begin{array}{l}\text { Yes } \\
\text { Yes }\end{array}$ & $\begin{array}{l}\text { Yes } \\
\text { Yes }\end{array}$ & $\begin{array}{l}\text { Yes } \\
\text { Yes }\end{array}$ & $\begin{array}{l}\text { Yes } \\
\text { Yes }\end{array}$ & $\begin{array}{l}\text { Yes } \\
\text { Yes }\end{array}$ & $\begin{array}{l}\text { Yes } \\
\text { Yes }\end{array}$ & $\begin{array}{l}\text { Yes } \\
\text { Yes }\end{array}$ \\
\hline Second-stage & & & & & & & \\
\hline VIX $(\log )$ & $-0.0059^{* * *}$ & $-0.0059^{* * *}$ & $-0.0060^{* * *}$ & $-0.0060^{* * *}$ & $-0.0054^{* *}$ & $-0.0060^{* * *}$ & $-0.0060^{* * *}$ \\
\hline$\%$ of Year FE & 0.209 & 0.211 & 0.215 & 0.215 & 0.184 & 0.213 & 0.215 \\
\hline Obs. & 4427 & 4427 & 4427 & 4427 & 4427 & 4427 & 4427 \\
\hline Countries & 161 & 161 & 161 & 161 & 161 & 161 & 161 \\
\hline adj. $R^{2}$ & 0.160 & 0.157 & 0.160 & 0.160 & 0.158 & 0.159 & 0.159 \\
\hline
\end{tabular}

With the within estimator, Peg_Open means a shift from float to peg given that a country is open.

With the within estimator, Open_Peg means a shift from closed to open given that a country is pegged.

${ }^{*},{ }^{* *}$, and $^{* * *}$ respectively denote significance at the 10,5 , and $1 \%$ levels.

Standard errors in parentheses. 
Table 4 - Looking for the Role of Global Banks

\begin{tabular}{|c|c|c|c|c|c|c|c|}
\hline \multirow[b]{2}{*}{ Dep. Var. } & $\overline{(1)}$ & $\overline{(2)}$ & $\overline{(3)}$ & $\overline{(4)}$ & 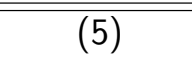 & 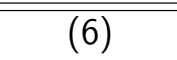 & $\overline{(7)}$ \\
\hline & \multicolumn{7}{|c|}{ Monetary Policy Independence Index } \\
\hline Peg_Open & $\begin{array}{l}-0.0400^{*} \\
(0.0224)\end{array}$ & $\begin{array}{c}-0.0772^{* * *} \\
(0.0219)\end{array}$ & $\begin{array}{c}-0.0400^{*} \\
(0.0223)\end{array}$ & $\begin{array}{c}-0.0691^{* * *} \\
(0.0218)\end{array}$ & $\begin{array}{c}-0.0796^{* * *} \\
(0.0219)\end{array}$ & $\begin{array}{c}-0.0712^{* * *} \\
(0.0216)\end{array}$ & $\begin{array}{c}-0.0489^{* *} \\
(0.0228)\end{array}$ \\
\hline Peg_Closed & $\begin{array}{l}-0.00844 \\
(0.0101)\end{array}$ & $\begin{array}{c}-0.0111 \\
(0.0102)\end{array}$ & $\begin{array}{r}-0.00851 \\
(0.0102)\end{array}$ & $\begin{array}{l}-0.00857 \\
(0.0102)\end{array}$ & $\begin{array}{r}-0.00772 \\
(0.0102)\end{array}$ & $\begin{array}{r}-0.00865 \\
(0.0102)\end{array}$ & $\begin{array}{r}-0.00521 \\
(0.0104)\end{array}$ \\
\hline Open_Peg & $\begin{array}{c}-0.0717^{* * *} \\
(0.0201)\end{array}$ & $\begin{array}{c}-0.0850^{* * *} \\
(0.0208)\end{array}$ & $\begin{array}{c}-0.0717^{* * *} \\
(0.0201)\end{array}$ & $\begin{array}{l}-0.0414^{*} \\
(0.0214)\end{array}$ & $\begin{array}{c}-0.0879^{* * *} \\
(0.0211)\end{array}$ & $\begin{array}{l}-0.0355 \\
(0.0216)\end{array}$ & $\begin{array}{c}-0.0537^{* *} \\
(0.0225)\end{array}$ \\
\hline Open_Float & $\begin{array}{l}-0.0119 \\
(0.0132)\end{array}$ & $\begin{array}{r}-0.00680 \\
(0.0137)\end{array}$ & $\begin{array}{c}-0.0118 \\
(0.0134)\end{array}$ & $\begin{array}{l}-0.0109 \\
(0.0131)\end{array}$ & $\begin{array}{r}-0.00415 \\
(0.0145)\end{array}$ & $\begin{array}{c}0.00371 \\
(0.0146)\end{array}$ & $\begin{array}{r}0.00580 \\
(0.0148)\end{array}$ \\
\hline Int. Res. & $\begin{array}{c}0.0646 \\
(0.0531)\end{array}$ & $\begin{array}{c}0.0771 \\
(0.0544)\end{array}$ & $\begin{array}{c}0.0646 \\
(0.0531)\end{array}$ & $\begin{array}{c}0.0615 \\
(0.0527)\end{array}$ & $\begin{array}{c}0.0785 \\
(0.0545)\end{array}$ & $\begin{array}{c}0.0598 \\
(0.0524)\end{array}$ & $\begin{array}{c}0.0606 \\
(0.0525)\end{array}$ \\
\hline Dom. Fin. & $\begin{array}{c}-0.0479^{* * *} \\
(0.0172)\end{array}$ & $\begin{array}{c}-0.0520^{* * *} \\
(0.0175)\end{array}$ & $\begin{array}{c}-0.0479^{* * *} \\
(0.0172)\end{array}$ & $\begin{array}{c}-0.0481^{* * *} \\
(0.0172)\end{array}$ & $\begin{array}{c}-0.0525^{* * *} \\
(0.0175)\end{array}$ & $\begin{array}{c}-0.0469^{* * *} \\
(0.0173)\end{array}$ & $\begin{array}{c}-0.0463^{* * *} \\
(0.0172)\end{array}$ \\
\hline DesynchCPI & $\begin{array}{l}-0.0121 \\
(0.0123)\end{array}$ & $\begin{array}{c}-0.0119 \\
(0.0124)\end{array}$ & $\begin{array}{c}-0.0121 \\
(0.0123)\end{array}$ & $\begin{array}{c}-0.0129 \\
(0.0123)\end{array}$ & $\begin{array}{c}-0.0114 \\
(0.0124)\end{array}$ & $\begin{array}{c}-0.0129 \\
(0.0123)\end{array}$ & $\begin{array}{c}-0.0120 \\
(0.0124)\end{array}$ \\
\hline Global Banks & $\begin{array}{c}-0.0203 \\
(0.0128)\end{array}$ & $\begin{array}{c}-0.0578^{* * *} \\
(0.0139)\end{array}$ & $\begin{array}{c}-0.0205 \\
(0.0141)\end{array}$ & $\begin{array}{l}-0.0210^{*} \\
(0.0126)\end{array}$ & $\begin{array}{c}-0.0453^{* * *} \\
(0.0150)\end{array}$ & $\begin{array}{c}-0.000427 \\
(0.0154)\end{array}$ & $\begin{array}{c}0.0193 \\
(0.0193)\end{array}$ \\
\hline Peg_Open x GlobalBk & $\begin{array}{c}-0.126^{* * *} \\
(0.0212)\end{array}$ & & $\begin{array}{c}-0.126^{* * *} \\
(0.0222)\end{array}$ & & & & $\begin{array}{c}-0.100^{* *} \\
(0.0500)\end{array}$ \\
\hline Peg_Closed x GlobalBk & & $\begin{array}{c}0.0367^{*} \\
(0.0221)\end{array}$ & $\begin{array}{l}0.000795 \\
(0.0218)\end{array}$ & & & & $\begin{array}{c}-0.0381 \\
(0.0253)\end{array}$ \\
\hline Open_Peg x GlobalBk & & & & $\begin{array}{c}-0.129^{* * *} \\
(0.0199)\end{array}$ & & $\begin{array}{c}-0.151^{* * *} \\
(0.0221)\end{array}$ & $\begin{array}{c}-0.0738 \\
(0.0457)\end{array}$ \\
\hline Open_Float x GlobalBk & & & & & $\begin{array}{c}-0.0159 \\
(0.0224)\end{array}$ & $\begin{array}{c}-0.0625^{* * *} \\
(0.0231)\end{array}$ & $\begin{array}{r}-0.0820^{* * *} \\
(0.0268)\end{array}$ \\
\hline Cons & $\begin{array}{l}0.512^{* * *} \\
(0.0169)\end{array}$ & $\begin{array}{l}0.517^{* * *} \\
(0.0166)\end{array}$ & $\begin{array}{l}0.512^{* * *} \\
(0.0168)\end{array}$ & $\begin{array}{l}0.513^{* * *} \\
(0.0167)\end{array}$ & $\begin{array}{l}0.516^{* * *} \\
(0.0167)\end{array}$ & $\begin{array}{l}0.512^{* * *} \\
(0.0170)\end{array}$ & $\begin{array}{l}0.509^{* * *} \\
(0.0172)\end{array}$ \\
\hline Country FE & Yes & Yes & Yes & Yes & Yes & Yes & Yes \\
\hline Year FE & Yes & Yes & Yes & Yes & Yes & Yes & Yes \\
\hline Second-stage & & & & & & & \\
\hline VIX $(\log )$ & $-0.0072^{* * *}$ & $-0.0074^{* * *}$ & $-0.0072^{* * *}$ & $-0.0074^{* * *}$ & $-0.0073^{* * *}$ & $-0.0080^{* * *}$ & $-0.0077^{* * *}$ \\
\hline$\%$ of Year FE & 0.293 & 0.300 & 0.293 & 0.306 & 0.292 & 0.339 & 0.327 \\
\hline Obs. & 4427 & 4427 & 4427 & 4427 & 4427 & 4427 & 4427 \\
\hline Countries & 161 & 161 & 161 & 161 & 161 & 161 & 161 \\
\hline adj. $R^{2}$ & 0.168 & 0.157 & 0.168 & 0.168 & 0.156 & 0.171 & 0.172 \\
\hline
\end{tabular}

With the within estimator, Peg_Open means a shift from float to peg given that a country is open.

With the within estimator, Open_Peg means a shift from closed to open given that a country is pegged.

${ }^{*},{ }^{* *}$, and ${ }^{* * *}$ respectively denote significance at the 10,5 , and $1 \%$ levels.

Standard errors in parentheses. 


\subsection{Looking for the Fluctuations of the Global Financial Cycle}

Table 5 focuses on another assumption, in connection with the dilemma from Passari and Rey (2015). I test whether this shift depends on the fluctuations of the global financial cycle: the trilemma is valid during the boom, i.e. with low risk aversion and little uncertainty, but it transforms into a dilemma during the bust. Because it is a cycle and not a linear temporal trend, I use the variation of the VIX and exploit moments of highest risk aversion with the Stress dummy variable.

This table supports the previous results with the same ranking of the trilemma configurations. Taken together, it provides compelling evidence that the assumption about a move between trilemma and dilemma according to the VIX is not valid. This result does not mean that the fluctuations of the global financial cycle are irrelevant, because the VIX is mainly at a high level of statistical significance in the two-step approach. The estimated year fixed effects are driven by the VIX, meaning that a high VIX sharply reduces trilemma trade-offs for policymakers. Yet, the statistical insignificance of interaction terms with Stress in Table 5 should be compared with the results in Tables 3 and 4, especially with global banks. It could be argued that the Stress variable is not correctly specified, but Nier et al. (2014) demonstrate that the VIX becomes the main driver of capital flows when the VIX is very high and I check other thresholds in the Online Appendix.

To sum up, it means that a high level of risk aversion and uncertainty per se probably make monetary policy independence drop. Yet, the impact of policymakers' decisions about financial openness and the exchange rate regime are more driven by the exposure of the global financial cycle through global players than by the VIX.

\section{Robustness}

\subsection{Alternative Specification and Endogeneity Issues.}

It can be argued that the identification strategy suffers from reverse causality issues because the stance of monetary policy is perhaps a determinant of financial openness and the exchange 
Table 5 - Looking for the Fluctuations of the Global Financial Cycle

\begin{tabular}{|c|c|c|c|c|c|c|}
\hline \multirow[b]{2}{*}{ Dep. Var. } & $\overline{(1)}$ & $\overline{(2)}$ & $\overline{(3)}$ & $(4)$ & 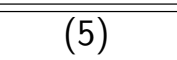 & $\overline{(6)}$ \\
\hline & \multicolumn{6}{|c|}{ Monetary Policy Independence Index } \\
\hline Peg_Open & $\begin{array}{c}-0.0795^{* * *} \\
(0.0226)\end{array}$ & $\begin{array}{c}-0.0654^{* * *} \\
(0.0230)\end{array}$ & $\begin{array}{c}-0.0871^{* * *} \\
(0.0214)\end{array}$ & $\begin{array}{c}-0.0719^{* * *} \\
(0.0221)\end{array}$ & $\begin{array}{c}-0.0726^{* * *} \\
(0.0228)\end{array}$ & $\begin{array}{c}-0.0581^{* *} \\
(0.0232)\end{array}$ \\
\hline Peg_Closed & $\begin{array}{l}-0.0104 \\
(0.0106)\end{array}$ & $\begin{array}{l}-0.00677 \\
(0.0106)\end{array}$ & $\begin{array}{c}-0.0106 \\
(0.00991)\end{array}$ & $\begin{array}{l}-0.00667 \\
(0.00989)\end{array}$ & $\begin{array}{l}-0.00773 \\
(0.0106)\end{array}$ & $\begin{array}{l}-0.00442 \\
(0.0106)\end{array}$ \\
\hline Open_Peg & $\begin{array}{c}-0.0963^{* * *} \\
(0.0231)\end{array}$ & $\begin{array}{c}-0.0802^{* * *} \\
(0.0212)\end{array}$ & $\begin{array}{c}-0.0893^{* * *} \\
(0.0229)\end{array}$ & $\begin{array}{c}-0.0743^{* * *} \\
(0.0212)\end{array}$ & $\begin{array}{c}-0.102^{* * *} \\
(0.0271)\end{array}$ & $\begin{array}{c}-0.0863^{* * *} \\
(0.0255)\end{array}$ \\
\hline Open_Float & $\begin{array}{l}-0.0224^{*} \\
(0.0127)\end{array}$ & $\begin{array}{l}-0.0107 \\
(0.0133)\end{array}$ & $\begin{array}{c}-0.0151 \\
(0.0134)\end{array}$ & $\begin{array}{l}-0.00401 \\
(0.0136)\end{array}$ & $\begin{array}{l}-0.0140 \\
(0.0135)\end{array}$ & $\begin{array}{l}-0.00319 \\
(0.0138)\end{array}$ \\
\hline Int. Res. & $\begin{array}{c}0.0662 \\
(0.0496)\end{array}$ & $\begin{array}{c}0.0789 \\
(0.0498)\end{array}$ & $\begin{array}{c}0.0657 \\
(0.0496)\end{array}$ & $\begin{array}{c}0.0784 \\
(0.0498)\end{array}$ & $\begin{array}{c}0.0647 \\
(0.0496)\end{array}$ & $\begin{array}{c}0.0776 \\
(0.0498)\end{array}$ \\
\hline Dom. Fin. & $\begin{array}{c}-0.0801^{* * *} \\
(0.0153)\end{array}$ & $\begin{array}{c}-0.0439^{* * *} \\
(0.0149)\end{array}$ & $\begin{array}{c}-0.0799^{* * *} \\
(0.0152)\end{array}$ & $\begin{array}{c}-0.0438^{* * *} \\
(0.0149)\end{array}$ & $\begin{array}{c}-0.0802^{* * *} \\
(0.0152)\end{array}$ & $\begin{array}{c}-0.0441^{* * *} \\
(0.0148)\end{array}$ \\
\hline DesynchCPI & $\begin{array}{c}-0.0182 \\
(0.0116)\end{array}$ & $\begin{array}{c}-0.0169 \\
(0.0118)\end{array}$ & $\begin{array}{c}-0.0181 \\
(0.0116)\end{array}$ & $\begin{array}{c}-0.0168 \\
(0.0119)\end{array}$ & $\begin{array}{l}-0.0176 \\
(0.0117)\end{array}$ & $\begin{array}{c}-0.0164 \\
(0.0119)\end{array}$ \\
\hline Stress & $\begin{array}{c}-0.00182 \\
(0.00837)\end{array}$ & $\begin{array}{l}0.000617 \\
(0.00831)\end{array}$ & $\begin{array}{c}0.00129 \\
(0.00667)\end{array}$ & $\begin{array}{c}0.00376 \\
(0.00673)\end{array}$ & $\begin{array}{c}0.00576 \\
(0.00962)\end{array}$ & $\begin{array}{c}0.00739 \\
(0.00966)\end{array}$ \\
\hline Global Investors & & $\begin{array}{c}-0.0546^{* * *} \\
(0.0146)\end{array}$ & & $\begin{array}{c}-0.0546^{* * *} \\
(0.0146)\end{array}$ & & $\begin{array}{c}-0.0545^{* * *} \\
(0.0146)\end{array}$ \\
\hline Global Banks & & $\begin{array}{c}-0.0471^{* * *} \\
(0.0121)\end{array}$ & & $\begin{array}{c}-0.0469^{* * *} \\
(0.0120)\end{array}$ & & $\begin{array}{c}-0.0468^{* * *} \\
(0.0120)\end{array}$ \\
\hline Peg_Open $\times$ Stress & $\begin{array}{l}-0.0264^{*} \\
(0.0159)\end{array}$ & $\begin{array}{c}-0.0222 \\
(0.0149)\end{array}$ & & & $\begin{array}{c}-0.0528 \\
(0.0443)\end{array}$ & $\begin{array}{c}-0.0503 \\
(0.0420)\end{array}$ \\
\hline Peg_Closed x Stress & $\begin{array}{c}-0.000927 \\
(0.0125)\end{array}$ & $\begin{array}{l}0.000102 \\
(0.0125)\end{array}$ & & & $\begin{array}{l}-0.00854 \\
(0.0134)\end{array}$ & $\begin{array}{c}-0.00672 \\
(0.0134)\end{array}$ \\
\hline Open_Peg $\times$ Stress & & & $\begin{array}{c}-0.0266 \\
(0.0161)\end{array}$ & $\begin{array}{c}-0.0224 \\
(0.0149)\end{array}$ & $\begin{array}{c}0.0201 \\
(0.0469)\end{array}$ & $\begin{array}{c}0.0226 \\
(0.0439)\end{array}$ \\
\hline Open_Float x Stress & & & $\begin{array}{l}-0.0167 \\
(0.0149)\end{array}$ & $\begin{array}{l}-0.0154 \\
(0.0145)\end{array}$ & $\begin{array}{c}-0.0211 \\
(0.0160)\end{array}$ & $\begin{array}{l}-0.0190 \\
(0.0156)\end{array}$ \\
\hline Cons & $\begin{array}{l}0.507^{* * *} \\
(0.0134)\end{array}$ & $\begin{array}{l}0.494^{* * *} \\
(0.0133)\end{array}$ & $\begin{array}{l}0.506^{* * *} \\
(0.0132)\end{array}$ & $\begin{array}{l}0.493^{* * *} \\
(0.0132)\end{array}$ & $\begin{array}{l}0.505^{* * *} \\
(0.0134)\end{array}$ & $\begin{array}{l}0.492^{* * *} \\
(0.0134)\end{array}$ \\
\hline Country FE & Yes & Yes & Yes & Yes & Yes & Yes \\
\hline Year FE & No & No & No & No & No & No \\
\hline Obs. & 4427 & 4427 & 4427 & 4427 & 4427 & 4427 \\
\hline Countries & 161 & 161 & 161 & 161 & 161 & 161 \\
\hline adj. $R^{2}$ & 0.112 & 0.128 & 0.112 & 0.128 & 0.112 & 0.128 \\
\hline
\end{tabular}

With the Within estimator, Peg_Open means a shift from float to peg given that a country is open.

With the Within estimator, Open_Peg means a shift from closed to open given that a country is pegged.

${ }^{*},{ }^{* *}$, and ${ }^{* * *}$ respectively denote significance at the 10,5 , and $1 \%$ levels.

Standard errors in parentheses. 
rate regime. The lagged explanatory variables used by Aizenman and Ito (2014) and Aizenman et al. (2016) are not entirely convincing because of the persistence of these variables. By contrast, I employ the methodology in Klein and Shambaugh (2015) as an alternative specification which is more robust to the endogeneity bias. They consider the following specification:

$$
\Delta R_{i t}=\alpha+\beta \Delta R_{b i t}+\epsilon_{i t}
$$

where $\Delta R_{i t}$ and $\Delta R_{b i t}$ are the annual first difference of the interest rate for the domestic country and base country, respectively. An increase in $\hat{\beta}$ means a decrease in monetary policy independence, following the discussion and conditions of Klein and Shambaugh (2015). They compare $\hat{\beta}$ and the $R^{2}$ statistic across subsamples by differentiating the four trilemma configurations. I present these four cases and distinguish between them by the fluctuations and the exposure to the global financial cycle.

Tables 6 and 7 consider the four trilemma cases according to the high presence of global investors and global banks, while Table 8 focuses on a time decomposition according to the high or low level of financial stress around the world. These tables support trilemma mechanisms, especially the lack of monetary policy independence in open pegged countries. It also supports the main result: the high presence of global players magnifies trilemma tradeoffs when the country is on the worst trilemma configuration, while the level of the VIX does not play a key role in this potential shift. Perhaps surprisingly, I find differences in the closed peg subsample and a significant $\hat{\beta}$ if and only if there is a low presence of these global players. However, the two subsamples are overly unbalanced. In the same way, the unanticipated coefficients on the open float subsample according to the level of financial stress could be explained by other factors, such as the differences in the presence of these two players.

\subsection{Additional Robustness}

Definition of Variables and Multicollinearity Concerns. The results in Tables 3 and 4 suggest multicollinearity and I do not find any effect of timing in trilemma configurations through conditional terms. Thus, I can test the stability of the results with simpler trilemma 
Table 6 - Other Specification à la Klein and Shambaugh (2015) - Sensitivity Analysis

\begin{tabular}{|c|c|c|c|c|c|c|c|c|}
\hline & \multicolumn{2}{|c|}{ Open Peg } & \multicolumn{2}{|c|}{ Open Float } & \multicolumn{2}{|c|}{ Closed Peg } & \multicolumn{2}{|c|}{ Closed Float } \\
\hline & $\begin{array}{c}\bar{\beta} \\
\text { (s.e.) }\end{array}$ & $\begin{array}{l}\text { Obs. } \\
{\left[R^{2}\right]}\end{array}$ & $\begin{array}{c}\bar{\beta} \\
\text { (s.e.) }\end{array}$ & $\begin{array}{l}\text { Obs. } \\
{\left[R^{2}\right]}\end{array}$ & $\begin{array}{c}\bar{\beta} \\
\text { (s.e.) }\end{array}$ & $\begin{array}{l}\text { Obs. } \\
{\left[R^{2}\right]}\end{array}$ & $\begin{array}{c}\beta \\
\text { (s.e.) }\end{array}$ & $\begin{array}{l}\text { Obs. } \\
{\left[R^{2}\right]}\end{array}$ \\
\hline Global Investors & $\begin{array}{c}0.84^{* * *} \\
(0.07)\end{array}$ & $\begin{array}{c}200 \\
{[0.57]}\end{array}$ & $\begin{array}{c}0.31 \\
(0.15)\end{array}$ & $\begin{array}{c}240 \\
{[0.003]}\end{array}$ & $\begin{array}{c}-0.21 \\
(0.28)\end{array}$ & $\begin{array}{c}86 \\
{[0.002]}\end{array}$ & $\begin{array}{l}-0.65 \\
(0.54)\end{array}$ & $\begin{array}{c}73 \\
{[0.007]}\end{array}$ \\
\hline No Gl. Investors & $\begin{array}{c}0.55^{* * *} \\
(0.09)\end{array}$ & $\begin{array}{c}291 \\
{[0.16]}\end{array}$ & $\begin{array}{c}0.18 \\
(0.15)\end{array}$ & $\begin{array}{c}542 \\
{[0.004]}\end{array}$ & $\begin{array}{c}0.48^{* * *} \\
(0.08)\end{array}$ & $\begin{array}{c}883 \\
{[0.006]}\end{array}$ & $\begin{array}{c}5258 \\
(5242)\end{array}$ & $\begin{array}{c}1072 \\
{[0.000]}\end{array}$ \\
\hline GI. Investors vs No & $0.28^{* *}$ & & 0.12 & & $-0.65^{* *}$ & & -5224 & \\
\hline
\end{tabular}

Subsample regressions of the form $\Delta R_{i t}=\alpha+\beta \Delta R_{b i t}+\epsilon_{i t}$. The term Global Investors means that the presence of foreign investors in domestic money and bond markets is higher than $15 \%$ of their domestic GDP. Entries in marginal row based on an interaction regression.

${ }^{*},{ }^{* *}$, and ${ }^{* * *}$ respectively denote significance at the 10,5 , and $1 \%$ levels.

Table 7 - Other Specification à la Klein and Shambaugh (2015) - Sensitivity Analysis

\begin{tabular}{|c|c|c|c|c|c|c|c|c|}
\hline & \multicolumn{2}{|c|}{ Open Peg } & \multicolumn{2}{|c|}{ Open Float } & \multicolumn{2}{|c|}{ Closed Peg } & \multicolumn{2}{|c|}{ Closed Float } \\
\hline & $\begin{array}{c}\bar{\beta} \\
\text { (s.e.) }\end{array}$ & $\begin{array}{l}\text { Obs. } \\
{\left[R^{2}\right]}\end{array}$ & $\begin{array}{c}\bar{\beta} \\
\text { (s.e.) }\end{array}$ & $\begin{array}{l}\text { Obs. } \\
{\left[R^{2}\right]}\end{array}$ & $\begin{array}{c}\bar{\beta} \\
\text { (s.e.) }\end{array}$ & $\begin{array}{l}\text { Obs. } \\
{\left[R^{2}\right]}\end{array}$ & $\begin{array}{c}\beta \\
\text { (s.e.) }\end{array}$ & $\begin{array}{l}\text { Obs. } \\
{\left[R^{2}\right]}\end{array}$ \\
\hline Global Banks & $\begin{array}{c}0.81^{* * *} \\
(0.06)\end{array}$ & $\begin{array}{c}224 \\
{[0.44]}\end{array}$ & $\begin{array}{l}0.25^{* *} \\
(0.12)\end{array}$ & $\begin{array}{c}228 \\
{[0.02]}\end{array}$ & $\begin{array}{c}0.24 \\
(0.09)\end{array}$ & $\begin{array}{c}176 \\
{[0.05]}\end{array}$ & $\begin{array}{l}12905 \\
(4888)\end{array}$ & $\begin{array}{c}106 \\
{[0.02]}\end{array}$ \\
\hline No G & $\begin{array}{c}0.51^{* * *} \\
(0.10)\end{array}$ & $\begin{array}{c}260 \\
{[0.15]}\end{array}$ & $\begin{array}{c}0.17 \\
(0.20)\end{array}$ & $\begin{array}{c}541 \\
{[0.002]}\end{array}$ & $\begin{array}{c}0.49^{* * *} \\
(0.09)\end{array}$ & $\begin{array}{c}735 \\
{[0.004]}\end{array}$ & $\begin{array}{c}4914 \\
(4888)\end{array}$ & $\begin{array}{c}1000 \\
{[0.000]}\end{array}$ \\
\hline Gl. Banks vs $N$ & $0.30^{* * *}$ & & 0.03 & & -0.30 & & 5343 & \\
\hline
\end{tabular}

Subsample regressions of the form $\Delta R_{i t}=\alpha+\beta \Delta R_{b i t}+\epsilon_{i t}$. The term Global Banks means that the presence of foreign global banks in a domestic economy is higher than $35 \%$ of their domestic GDP. Entries in marginal row based on an interaction regression.

${ }^{*},{ }^{* *}$, and ${ }^{* * *}$ respectively denote significance at the 10,5 , and $1 \%$ levels.

Table 8 - Other Specification à la Klein and Shambaugh (2015) - Sensitivity Analysis

\begin{tabular}{|c|c|c|c|c|c|c|c|c|}
\hline & \multicolumn{2}{|c|}{ Open Peg } & \multicolumn{2}{|c|}{ Open Float } & \multicolumn{2}{|c|}{ Closed Peg } & \multicolumn{2}{|c|}{ Closed Float } \\
\hline & $\begin{array}{c}\bar{\beta} \\
\text { (s.e.) }\end{array}$ & $\begin{array}{l}\text { Obs. } \\
{\left[R^{2}\right]}\end{array}$ & $\begin{array}{c}\bar{\beta} \\
\text { (s.e.) }\end{array}$ & $\begin{array}{l}\text { Obs. } \\
{\left[R^{2}\right]}\end{array}$ & $\begin{array}{c}\bar{\beta} \\
\text { (s.e.) }\end{array}$ & $\begin{array}{l}\text { Obs. } \\
{\left[R^{2}\right]}\end{array}$ & $\begin{array}{c}\bar{\beta} \\
\text { (s.e.) }\end{array}$ & $\begin{array}{l}\text { Obs. } \\
{\left[R^{2}\right]}\end{array}$ \\
\hline Stress & $\begin{array}{c}0.52^{* * *} \\
(0.09)\end{array}$ & $\begin{array}{c}221 \\
{[0.16]}\end{array}$ & $\begin{array}{l}-0.43 \\
(0.26)\end{array}$ & $\begin{array}{c}369 \\
{[0.008]}\end{array}$ & $\begin{array}{l}0.31^{* *} \\
(0.14)\end{array}$ & $\begin{array}{c}359 \\
{[0.01]}\end{array}$ & $\begin{array}{c}1.70 \\
(1.49)\end{array}$ & $\begin{array}{c}462 \\
{[0.003]}\end{array}$ \\
\hline No Stress & $\begin{array}{c}0.71^{* * *} \\
(0.10)\end{array}$ & $\begin{array}{c}270 \\
{[0.27]}\end{array}$ & $\begin{array}{c}0.58^{* * *} \\
(0.14)\end{array}$ & $\begin{array}{c}413 \\
{[0.06]}\end{array}$ & $\begin{array}{c}0.48^{* * *} \\
(0.10)\end{array}$ & $\begin{array}{c}610 \\
{[0.007]}\end{array}$ & $\begin{array}{c}7209 \\
(7211)\end{array}$ & $\begin{array}{c}685 \\
{[0.000]}\end{array}$ \\
\hline Stress vs No & -0.17 & & $-0.93^{* *}$ & & -0.16 & & -7263 & \\
\hline
\end{tabular}

Subsample regressions of the form $\Delta R_{i t}=\alpha+\beta \Delta R_{b i t}+\epsilon_{i t}$. The term Stress means that the global risk aversion and uncertainty around the world is high, namely the VIX is higher than 23 .

Entries in marginal row based on an interaction regression.

${ }^{*},{ }^{* *}$, and ${ }^{* * *}$ respectively denote significance at the 10,5 , and $1 \%$ levels. 
decision variables, namely $P e g$, Open, and the interact term. Table A1 in the Online Appendix ${ }^{19}$ provides the same results as Table 2 . The small difference in the coefficient reflecting the worst trilemma case is explained by the three feasible cases of the interaction term, including a shift from closed peg to open peg, a shift from open float to open peg, or a simultaneous shift from closed float to open peg. Table A2 investigates the role of global players based on the previous methodology. It sharply restricts multicollinearity problems, even if the Global Investors variable appears quite highly correlated to other variables. I find close quantitative results, especially when the domestic country is highly dependent on global players and decides to go to the worst trilemma configuration.

The coefficient of global banks alone is sometimes positive when an interaction is included. This effect only exists for columns (3), (4), and (8) when there are interactions with financial openness or a pegged exchange rate. It means that the high presence of global banks in relatively financially closed floating countries is positively associated with monetary policy independence. Consistent with Goldberg (2013), the heterogeneity of global banks' roles and strategies calls for mixed evidence. A global bank affiliate could help to maintain economic resilience with access to foreign funds, whereas domestic financial conditions break down in the case of a domestic negative shock.

The Exposure to the Global Financial Cycle. Details on the measures of the exposure to the global financial cycle through global investors and global banks are given in the Online Appendix. The results are not driven by specific outliers such as offshore centers around the world. I assess the strength of the results by comparing the ad hoc thresholds with new ones. I also successively investigate continuous measures for both trilemma policymakers' decisions and the domestic presence of global players by providing various interaction terms and plotting elasticities. They do not substantively bias the baseline estimates.

The Fluctuations of the Global Financial Cycle. I carefully test the assumptions on the fluctuations of the global financial cycle. The Online Appendix investigates various global factors like the TED spread which could be estimated as a proxy of the global financial cycle.

\footnotetext{
${ }^{19}$ It is available on the author's website (Link).
} 
Again, I test other thresholds and extend this analysis by estimating an endogenous threshold. In all cases, the results remain close to the baseline estimates.

\section{Is It Really Monetary Policy Autonomy? Other Monetary Condition Variables. I} test multiple measures for the correlation of GDP and inflation cycles in the Online Appendix. I ensure that the results imply effective monetary policy independence. The comovement of interest rates appears to be a good proxy of monetary policy independence, but Rey (2015) and Rey (2016) distinguish between monetary policy instruments and results. I cannot credibly say that all monetary policy channels go through the short-term interest rate. She uses credit volumes, house prices, and equity indices as other proxies of monetary policy autonomy, whereas Borio (2014) and Drehmann et al. (2012) analyze them as proxies of national financial cycles. This strategy is replicated in the Online Appendix by using the dependent variable of the base country as an explanatory variable. This alternative approach could reflect effective monetary policy autonomy, because they are determinants of these national financial cycles. However, there is no monthly data of these financial variables to closely follow the baseline specification. The financial variable of the base country is generally irrelevant, probably because of this data frequency. On the one hand, the presence of global players positively affects the financial variable, with the notable exception of global investors on equity markets at a very low level of statistical significance. On the other hand, trilemma decisions have some impact. Financial openness pushes up equity prices and credit with cross-border flow supply. But the effect of exchange-rate regime is quite unclear. These unlinear and mixed evidence about exchange-rate regime is not sufficient to validate the Rey (2015) hypothesis.

Controlling for Financial Crises and Country Size. Country size and various types of financial crises do not change the main result. They also reflect the potential heterogenous role of global banks à la Goldberg (2013), notably because of differences between advanced economies and the emerging world. 


\section{Conclusion}

Trilemma does not morph into a dilemma. In contrast to Rey (2015), the global financial cycle worsens trilemma configurations, especially when global investors and global players play a major role in the domestic economy. The sensitivity to the global financial cycle depends less on the fluctuations of these financial forces than on the presence of global investors and global banks. The presence per se of global players generally does not worsen the trilemma, but their presence, associated with specific policymaker decisions, exacerbates these tradeoffs. Global investors reinforce transmission channels between the exchange rate regime and monetary policy autonomy, but less with financial openness, while global banks play a more active role for both policy decisions. This paper also confirm that the comovement of policy interest rates is a good proxy of monetary policy independence. First, I account for this by controlling for the correlation of business cycles and inflation cycles. Second, I investigate the financial variables that are considered as monetary policy results. They are consistent with the key results.

The findings of this paper illustrate the importance of global players for the international monetary and financial system, and calls for more macroprudential regulation. The resilience of domestic economies depends less on a monotonic degree of financial liberalization than on the effectiveness of capital flow management. There are a number of issues that are beyond the scope of this paper. First, it focuses on the traditional Mundellian trilemma in this new world, whereas monetary policy combines goals of monetary stability and financial stability. I include financial forces but do not explicitly interact this trilemma with the financial trilemma. Second, there is a complementary strand in the literature that focuses on central bank characteristics: for instance, the sensitivity of domestic economies to these financial forces could depend on the governors of central banks. 


\section{References}

Ahmed, S., Zlate, A., 2014. Capital Flows to Emerging Market Economies: A Brave New World? Journal of International Money and Finance 48 (PB), 221-248.

Aizenman, J., 2013. The Impossible Trinity. From the Policy Trilemma to the Policy Quadrilemma. Global Journal of Economics 2 (1).

Aizenman, J., Chinn, M. D., Ito, H., Dec. 2008. Assessing the Emerging Global Financial Architecture: Measuring the Trilemma's Configurations over Time. NBER Working Papers 14533, National Bureau of Economic Research, Inc.

Aizenman, J., Chinn, M. D., Ito, H., 2016. Monetary Policy Spillovers and the Trilemma in the New Normal: Periphery Country Sensitivity to Core Country Conditions. Journal of International Money and Finance 68 (C), 298-330.

Aizenman, J., Ito, H., 2012. Trilemma Policy Convergence Patterns and Output Volatility. The North American Journal of Economics and Finance 23 (3), 269-285.

Aizenman, J., Ito, H., 2014. Living with the Trilemma Constraint: Relative Trilemma Policy Divergence, Crises, and Output Losses for Developing Countries. Journal of International Money and Finance 49 (PA), 28-51.

Avdjiev, S., Gambacorta, L., Goldberg, L. S., Schiaffi, S., 2017. The Shifting Drivers of International Capital Flows. NBER Working Papers 23565, National Bureau of Economic Research, Inc.

Blanchard, O., Ostry, J. D., Ghosh, A. R., Chamon, M., Oct. 2015. Are Capital Inflows Expansionary or Contractionary? Theory, Policy Implications, and Some Evidence. NBER Working Papers 21619, National Bureau of Economic Research, Inc.

Bloom, N., 05 2009. The Impact of Uncertainty Shocks. Econometrica 77 (3), 623-685.

Borio, C., 2014. The Financial Cycle and Macroeconomics: What have we learnt? Journal of Banking \& Finance 45, 182-198.

Bruno, V., Shin, H. S., 2015a. Capital Flows and the Risk-Taking Channel of Monetary Policy. Journal of Monetary Economics 71 (C), 119-132.

Bruno, V., Shin, H. S., 2015b. Cross-Border Banking and Global Liquidity. Review of Economic Studies 82 (2), 535-564.

Cerutti, E., Claessens, S., Puy, M. D., 2015. Push Factors and Capital Flows to Emerging markets: Why knowing your lender matters more than fundamentals. IMF Working Papers 15-127, International Monetary Fund.

Chinn, M. D., Ito, H., October 2006. What Matters for Financial Development? Capital Controls, Institutions, and Interactions. Journal of Development Economics 81 (1), 163192.

di Giovanni, J., Shambaugh, J. C., March 2008. The Impact of Foreign Interest Rates on the Economy: The Role of the Exchange Rate Regime. Journal of International Economics 74 (2), 341-361.

Drehmann, M., Borio, C. E., Tsatsaronis, K., 2012. Characterising the Financial Cycle: Don't Lose Sight of the Medium term! BIS Working Papers 380, Bank for International Settlements.

Farhi, E., Werning, I., Jun. 2012. Dealing with the Trilemma: Optimal Capital Controls with Fixed Exchange Rates. NBER Working Papers 18199, National Bureau of Economic 
Research, Inc.

Fernández, A., Klein, M. W., Rebucci, A., Schindler, M., Uribe, M., 2015. Capital Control Measures: A New Dataset. IMF Working Papers 15-80, International Monetary Fund.

Forbes, K., Fratzscher, M., , Straub, R., 2015. Capital Controls and Macroprudential Measures: What are they good for? Journal of International Economics 96, 76 -97.

Forbes, K. J., Warnock, F. E., 2012. Capital Flow Waves: Surges, Stops, Flight, and Retrenchment. Journal of International Economics 88 (2), 235-251.

Ghosh, A. R., Qureshi, M. S., Kim, J. I., Zalduendo, J., 2014. Surges. Journal of International Economics 92 (2), 266-285.

Goldberg, L. S., Oct. 2013. Banking Globalization, Transmission, and Monetary Policy Autonomy. NBER Working Papers 19497, National Bureau of Economic Research, Inc.

Han, X., Wei, S.-J., Nov. 2016. International Transmissions of Monetary Shocks: Between a Trilemma and a Dilemma. NBER Working Papers 22812, National Bureau of Economic Research, Inc.

Hofmann, B., Takàts, E., September 2015. International Monetary Spillovers. BIS Quarterly Review.

Klein, M. W., Nov. 2012. Capital Controls: Gates versus Walls. NBER Working Papers 18526, National Bureau of Economic Research, Inc.

Klein, M. W., Shambaugh, J. C., Dec. 2006. The Nature of Exchange Rate Regimes. NBER Working Papers 12729, National Bureau of Economic Research, Inc.

Klein, M. W., Shambaugh, J. C., October 2015. Rounding the Corners of the Policy Trilemma: Sources of Monetary Policy Autonomy. American Economic Journal: Macroeconomics 7 (4), 33-66.

Lane, P. R., Milesi-Ferretti, G. M., November 2007. The External Wealth of Nations Mark II: Revised and Extended Estimates of Foreign Assets and Liabilities, 1970-2004. Journal of International Economics 73 (2), 223-250.

Levy-Yeyati, E., Sturzenegger, F., August 2005. Classifying Exchange Rate Regimes: Deeds vs. Words. European Economic Review 49 (6), 1603-1635.

Lorenzoni, G., 2008. Inefficient credit booms. The Review of Economic Studies 75 (3), 809833.

Mendoza, E. G., Terrones, M. E., May 2008. An Anatomy Of Credit Booms: Evidence From Macro Aggregates And Micro Data. NBER Working Papers 14049, National Bureau of Economic Research, Inc.

Miranda-Agrippino, S., Rey, H., Nov. 2015. World Asset Markets and the Global Financial Cycle. NBER Working Papers 21722, National Bureau of Economic Research, Inc.

Mundell, R. A., November 1963. Capital Mobility and Stabilization Policy under Fixed and Flexible Exchange Rates. Canadian Journal of Economics and Political Science 29, 475485.

Nier, E., Sedik, T. S., Mondino, T., Oct. 2014. Gross Private Capital Flows to Emerging Markets: Can the Global Financial Cycle Be Tamed? IMF Working Papers 14/196, International Monetary Fund.

Obstfeld, M., 2015. Trilemmas and Tradeoffs: Living with Financial Globalization. BIS Working Papers 480, Bank for International Settlements. 
Obstfeld, M., Shambaugh, J. C., Taylor, A. M., August 2005. The Trilemma in History: Tradeoffs Among Exchange Rates, Monetary Policies, and Capital Mobility. The Review of Economics and Statistics 87 (3), 423-438.

Obstfeld, M., Shambaugh, J. C., Taylor, A. M., April 2010. Financial Stability, the Trilemma, and International Reserves. American Economic Journal: Macroeconomics 2 (2), 57-94.

Passari, E., Rey, H., 05 2015. Financial Flows and the International Monetary System. Economic Journal 0 (584), 675-698.

Popper, H., Alex, M., Bird, G., 2013. Trilemma Stability and International Macroeconomic Archetypes. European Economic Review 64, 181-193.

Quinn, D., Schindler, M., Toyoda, A. M., August 2011. Assessing Measures of Financial Openness and Integration. IMF Economic Review 59 (3), 488-522.

Reinhart, C. M., Rogoff, K. S., 2004. The Modern History of Exchange Rate Arrangements: A Reinterpretation. The Quarterly Journal of Economics 119 (1), 1-48.

Rey, H., May 2015. Dilemma not Trilemma: The global Financial Cycle and Monetary Policy Independence. NBER Working Papers 21162, National Bureau of Economic Research, Inc.

Rey, H., 2016. International Channels of Transmission of Monetary Policy and the Mundellian Trilemma. NBER Working Papers 21852, National Bureau of Economic Research, Inc.

Ricchi, L. A., Shi, W., March 2016. Trilemma or Dilemma: Inspecting the Heterogeneous Response of Local Currency Interest Rates to Foreign Rates. IMF Working Papers.

Schindler, M., April 2009. Measuring Financial Integration: A New Data Set. IMF Staff Papers 56 (1), 222-238.

Schularick, M., Taylor, A. M., 2012. Credit Booms Gone Bust: Monetary Policy, Leverage Cycles, and Financial Crises, 1870-2008. American Economic Review 102 (2), 1029-61.

Shambaugh, J. C., February 2004. The Effect of Fixed Exchange Rates on Monetary Policy. Quarterly Journal of Economics 119 (1), 301-352. 


\section{Appendix 1: List of Countries, Data Sources and Descriptive Statistics}

Table A.1 - Descriptive Statistics

\begin{tabular}{|c|c|c|c|c|c|c|}
\hline Variable & Obs. & Countries & Mean & Std. Dev & Min & Max \\
\hline \multicolumn{7}{|c|}{ Monetary Policy Autonomy } \\
\hline MI & 4427 & 161 & 0.432 & 0.183 & 0 & 0.967 \\
\hline DesynchCPI & 4427 & 161 & 0.161 & 0.207 & 0.00009 & 0.998 \\
\hline Synclnfl (annual) & 4385 & 160 & 0.834 & 0.277 & 0.0002 & 1 \\
\hline SyncGDP (annual) & 4400 & 161 & 0.911 & 0.226 & 0.002 & 1 \\
\hline \multicolumn{7}{|c|}{ Policy Choices: Binary vs Continuous Indices } \\
\hline Peg (binary) & 4427 & 161 & 0.448 & 0.497 & 0 & 1 \\
\hline Open (binary) & 4427 & 161 & 0.349 & 0.477 & 0 & 1 \\
\hline ERS (continuous) & 4427 & 161 & 0.622 & 0.321 & 0.005 & 1 \\
\hline Kaopen (continuous) & 4427 & 161 & 0.466 & 0.355 & 0 & 1 \\
\hline Int. Reserves/GDP & 4427 & 161 & 0.137 & 0.158 & 0.00009 & 1.567 \\
\hline \multicolumn{7}{|c|}{ Depth of domestic financial system } \\
\hline PrivateCredit/GDP & 4418 & 161 & 0.457 & 0.415 & 0.007 & 3.122 \\
\hline Domestic Financial/GDP & 4427 & 161 & 0.584 & 0.496 & -0.791 & 3.665 \\
\hline \multicolumn{7}{|c|}{ Role of Global Investors: International Debt Securities } \\
\hline IDS/GDP (continuous) & 2734 & 111 & 0.148 & 0.353 & 0 & 5.571 \\
\hline Global Investors (binary) & 4427 & 161 & 0.162 & 0.368 & 0 & 1 \\
\hline \multicolumn{7}{|c|}{ Role of Global Banks: Consolidated Foreign Claims } \\
\hline CFC/GDP (continuous) & 3552 & 158 & 0.502 & 1.984 & 0.00009 & 42.368 \\
\hline Global Banks (binary) & 4427 & 161 & 0.217 & 0.413 & 0 & 1 \\
\hline \multicolumn{7}{|c|}{ Global Financial Cycle } \\
\hline VIX (mean, log) & 4427 & 161 & 3.0 & 0.292 & 2.39 & 3.60 \\
\hline VIX (std) & 4427 & 161 & 4.269 & 3.555 & 0.916 & 16.972 \\
\hline Stress (binary) & 4427 & 161 & 0.386 & 0.487 & 0 & 1 \\
\hline Oil Price (mean, log) & 4427 & 161 & 1.556 & 0.348 & 0.447 & 2.123 \\
\hline TED spread (mean) & 3558 & 159 & 0.598 & 0.365 & 0.19 & 1.55 \\
\hline \multicolumn{7}{|c|}{ Effective Monetary Policy Autonomy } \\
\hline House Price Index (real, log) & 1238 & 56 & 1.876 & 0.185 & 0.802 & 2.31 \\
\hline Equity Index (nom., log) & 1703 & 67 & 2.688 & 1.002 & -1.698 & 5.052 \\
\hline
\end{tabular}


Table A.2 - List of Countries (first part)

\begin{tabular}{crcccc}
\hline \multicolumn{2}{c}{ West Europe, North Am. } & \multicolumn{2}{c}{ Europe and Central Asia } & \multicolumn{2}{c}{ South,East Asia and Pacific } \\
\hline Austria & $1970-2013$ & Albania & $1996-2013$ & Australia & $1970-2013$ \\
Belgium & $1970-2012$ & Armenia & $1996-2013$ & Bangladesh & $1993-2012$ \\
Canada & $1970-2008$ & Azerbaijan & $2009-2013$ & Bhutan & $2004-2013$ \\
Denmark & $1970-2013$ & Belarus & $1996-2013$ & China & $1986-2013$ \\
France & $1970-2013$ & Bulgaria & $1994-2013$ & Fiji & $1975-2009$ \\
Finland & $1970-2013$ & Croatia & $1996-2013$ & Hong Kong & $1990-2013$ \\
Germany & $1970-2013$ & Cyprus & $1975-2012$ & India & $1970-2013$ \\
Greece & $1970-2013$ & Czech Rep. & $1995-2013$ & Indonesia & $1983-2013$ \\
Iceland & $1983-2013$ & Estonia & $1996-2010$ & Japan & $1970-2013$ \\
Italy & $1970-2013$ & Georgia & $1996-2013$ & Korea & $1983-2013$ \\
Ireland & $1976-2013$ & Hungary & $1991-2013$ & Lao PDR & $1989-2010$ \\
Malta & $1972-2013$ & Kazakhstan & $1996-2013$ & Malaysia & $1983-2013$ \\
Netherlands & $1970-2013$ & Kyrgyz Rep. & $1997-2007$ & Maldives & $2006-2013$ \\
Norway & $1970-2006$ & Latvia & $1996-2012$ & Micronesia St. & $2008-2012$ \\
Portugal & $1983-2013$ & Lithuania & $1996-2012$ & Nepal & $1974-2013$ \\
Spain & $1970-2013$ & Mongolia & $1995-2013$ & New Zealand & $1983-2010$ \\
Sweden & $1970-2013$ & Moldova & $1996-2013$ & Pakistan & $1970-2013$ \\
Switzerland & $1995-2013$ & Poland & $1991-2013$ & Papua New Guinea & $2010-2013$ \\
United Kingdom & $1970-2013$ & Romania & $1994-2013$ & Philippines & $1983-2013$ \\
& & Russian Fed. & $1996-2013$ & Samoa & $1983-2012$ \\
& & Slovak Rep. & $1996-2008$ & Singapore & $1983-2013$ \\
& & Slovenia & $1996-2012$ & Solomon Island & $1982-2013$ \\
& & Tajikistan & $2000-2013$ & Sri Lanka & $1970-2012$ \\
& & Turkey & $1970-2013$ & Thailand & $1997-2013$ \\
& & Ukraine & $1996-2013$ & Tonga & $1990-2013$ \\
& & & Vanuatu & 2000 \\
& & & Vietnam & $1996-2012$
\end{tabular}


Table A.3 - List of Countries (second part)

\begin{tabular}{|c|c|c|c|c|c|}
\hline \multicolumn{2}{|c|}{ Latin America and Caribbean } & \multicolumn{4}{|c|}{ Middle East,North Africa and Sub-Saharan Africa } \\
\hline Antigua and Barb. & 1998-2009 & Algeria & $1974-2013$ & Guinea-Bisseau & 1987-2012 \\
\hline Argentina & 1988-2013 & Djibouti & $1997-2007$ & Guinea & 2004-2005 \\
\hline Bahamas & 1983-2012 & Egypt, Rep & $1970-2013$ & Kenya & 1970-2013 \\
\hline Barbados & 1983-2009 & Iran & 1970-1979 & Lesotho & $2002-2013$ \\
\hline Belize & $1985-2013$ & Israel & $1982-2013$ & Liberia & 2001-2012 \\
\hline Bolivia & $1970-2013$ & Jordan & $1976-2012$ & Madagascar & 1970-2012 \\
\hline Brazil & 1983-2013 & Kuwait & $1970-2013$ & Malawi & 1980-2012 \\
\hline Chile & 1983-2013 & Lebanon & 2008-2012 & Mauritanie & 1985-2012 \\
\hline Colombia & $1970-2013$ & Libya & 2001-2009 & Mauritius & 1976-2013 \\
\hline Costa Rica & 1983-2013 & Morocco & $1970-2013$ & Mozambique & 1994-2013 \\
\hline Dominica & $1982-2013$ & Oman & 2004-2013 & Namibia & 2002-2013 \\
\hline Dominican Rep. & $1970-2013$ & Qatar & 2003-2013 & Niger & $1970-2012$ \\
\hline El Salvador & $1970-2012$ & Saudi Arabia & $1997-2012$ & Nigeria & $1970-2013$ \\
\hline Grenada & 1981-2013 & Tunisia & $1987-2012$ & Rwanda & 1970-2005 \\
\hline Guatemala & $1970-2013$ & Angola & $1995-2013$ & Sao Tome & 2001-2013 \\
\hline Guyana & 1994-2013 & Benin & 1992-2012 & Senegal & 1970-2012 \\
\hline Haiti & 1994-2013 & Botswana & $1976-2013$ & Seychelles & 1981-2013 \\
\hline Honduras & $1979-2013$ & Burkina Faso & 1988-2012 & Sierra Leone & 2006-2013 \\
\hline Jamaica & 1983-2013 & Burundi & $1977-2013$ & South Africa & $1970-2013$ \\
\hline Mexico & 1983-2013 & Cameroon & $1970-2013$ & Sudan & 1978-1984 \\
\hline Nicaragua & 1999-2013 & Cape Verde & $1992-2013$ & Swaziland & 1974-2013 \\
\hline Panama & $1986-2013$ & Central Afr. Rep. & 1981-2013 & Tanzania & 1988-2013 \\
\hline Paraguay & $1990-2013$ & Chad & 1983-2013 & Togo & $1970-2012$ \\
\hline Peru & 1983-2012 & Congo Rep. & $1984-2013$ & Uganda & 1992-2013 \\
\hline St Kitts and N. & 1998-2013 & Congo Dem. Rep. & $1982-2012$ & Zambia & 1985-2013 \\
\hline St Lucia & 1983-2013 & Ivory Coast & 1983-2012 & Zimbabwe & 1995-2005 \\
\hline St Vincent & $1985-2008$ & Equatorial Guinea & $1985-2013$ & & \\
\hline Suriname & $1991-2013$ & Ethiopia & $1985-2008$ & & \\
\hline Trinidad and Tob. & 1983-2009 & Gabon & $1970-2013$ & & \\
\hline Uruguay & 1983-2013 & Gambia & $1977-2013$ & & \\
\hline Venezuela & 2008-2013 & Ghana & $1970-2013$ & & \\
\hline
\end{tabular}


Table A.4 - Data Sources

\begin{tabular}{|c|c|c|}
\hline Variable & Description & Source \\
\hline \multicolumn{3}{|c|}{ Monetary Policy Autonomy } \\
\hline MPI & $\begin{array}{l}\text { Continuous normalized index based on the annual } \\
\text { correlation between the monthly interest rate of the } \\
\text { domestic and the base country. }\end{array}$ & Aizenman et al. (2008) updated \\
\hline DesynchCPI & Similar methodology with monthly CPI. & IMF, CB, Datastream \\
\hline Synclnfl & Annual CPI growth. & IMF, CB, Datastream \\
\hline SyncGDP & Annual GDP growth. & World Bank, Datastream \\
\hline \multicolumn{3}{|c|}{ Policy Choices: Binary vs Continuous Indices } \\
\hline Peg & $\begin{array}{l}\text { Binary index based on the annual standard deviations of } \\
\text { the monthly exchange rate of the domestic and the base } \\
\text { country. }\end{array}$ & Klein and Shambaugh (2015) \\
\hline ERS & Continuous normalized index based on close methodology. & Aizenman et al. (2008) updated \\
\hline Open & $\begin{array}{l}\text { Binary de jure measure of financial liberalization. } \\
\text { Threshold based on Goldberg (2013) } \\
\text { and Klein and Shambaugh (2015). }\end{array}$ & Aizenman et al. (2008) updated \\
\hline Kaopen & Continuous de jure measure of financial liberalization & Aizenman et al. (2008) updated \\
\hline Int. Res./GDP & $\begin{array}{r}\text { Ratio of international reserves to GDP, excluding gold. } \\
\text { Depth of domestic financial system }\end{array}$ & World Bank, CB \\
\hline Pri. Cred./GDP & $\begin{array}{l}\text { Domestic credit to private sector as a share of GDP. } \\
\text { It refers to financial resources provided to the private } \\
\text { sector by financial corporations. }\end{array}$ & World Bank \\
\hline Dom. Fin./GDP & $\begin{array}{l}\text { Domestic credit provided by financial sector. It measures } \\
\text { banking sector depth and financial sector development } \\
\text { in terms of size. }\end{array}$ & World Bank \\
\hline \multicolumn{3}{|c|}{ Role of Global Investors: International Debt Securities } \\
\hline IDS/GDP & $\begin{array}{l}\text { International debt securities are borrowing in money and } \\
\text { bond markets are those issued in a market other than the } \\
\text { local market of the country where the borrower resides. } \\
\text { Only resident issuers. These amount and GDP are in } \\
\text { US current dollar. }\end{array}$ & BIS, author's calculation \\
\hline Global Investors & $\begin{array}{l}\text { Binary version. Equal to } 1 \text { if ratio is higher than its } 75^{\text {th }} \\
\text { percentile of the distribution, that is } 15 \% \text { of GDP. }\end{array}$ & BIS, author's calculation \\
\hline \multicolumn{3}{|c|}{ Role of Global Banks: Consolidated Foreign Claims } \\
\hline CFC/GDP & $\begin{array}{l}\text { Consolidated foreign claims of reporting banks on } \\
\text { individual countries that corresponds to the effective role } \\
\text { of global banks in the domestic financial system. These } \\
\text { amount and GDP are in US current dollar. Computed } \\
\text { on immediate counterparty basis. }\end{array}$ & BIS, author's calculation \\
\hline Global Banks & $\begin{array}{l}\text { Binary version. Equal to } 1 \text { if ratio is higher than its } 75^{\text {th }} \\
\text { percentile of the distribution, that is 35\% of GDP. } \\
\text { Global Financial Cycle }\end{array}$ & BIS, author's calculation \\
\hline VIX & Conventional measure of risk aversion and uncertainty. & Bloom (2009) updated \\
\hline Stress & $\begin{array}{l}\text { Binary measure. Equal to } 1 \text { if ratio is higher than its } 75^{t h} \\
\text { percentile of the distribution, that is } 23 \text {. }\end{array}$ & Author's calculation. \\
\hline Oil Price & World Crude Oil, US dollars. & Datastream \\
\hline TED spread & $\begin{array}{l}\text { Percent, annual mean. } \\
\qquad \text { Effective Monetary Policy Autonomy }\end{array}$ & FED St Louis \\
\hline Pri. Cred./GDP & $\begin{array}{l}\text { Domestic credit to private sector as a share of GDP. } \\
\text { It refers to financial resources provided to the private } \\
\text { sector by financial corporations. }\end{array}$ & World Bank \\
\hline $\begin{array}{l}\text { House Prices } \\
\text { Equity }\end{array}$ & $\begin{array}{l}\text { Real house price index. } \\
\text { Nominal equity index. } 42\end{array}$ & $\begin{array}{l}\text { BIS, Cesa-Bianchi website, } \\
\text { Datastream, MSCl, } \\
\text { Schularick and Taylor (2012) }\end{array}$ \\
\hline
\end{tabular}




\section{Appendix 2: Inflation Cycles}

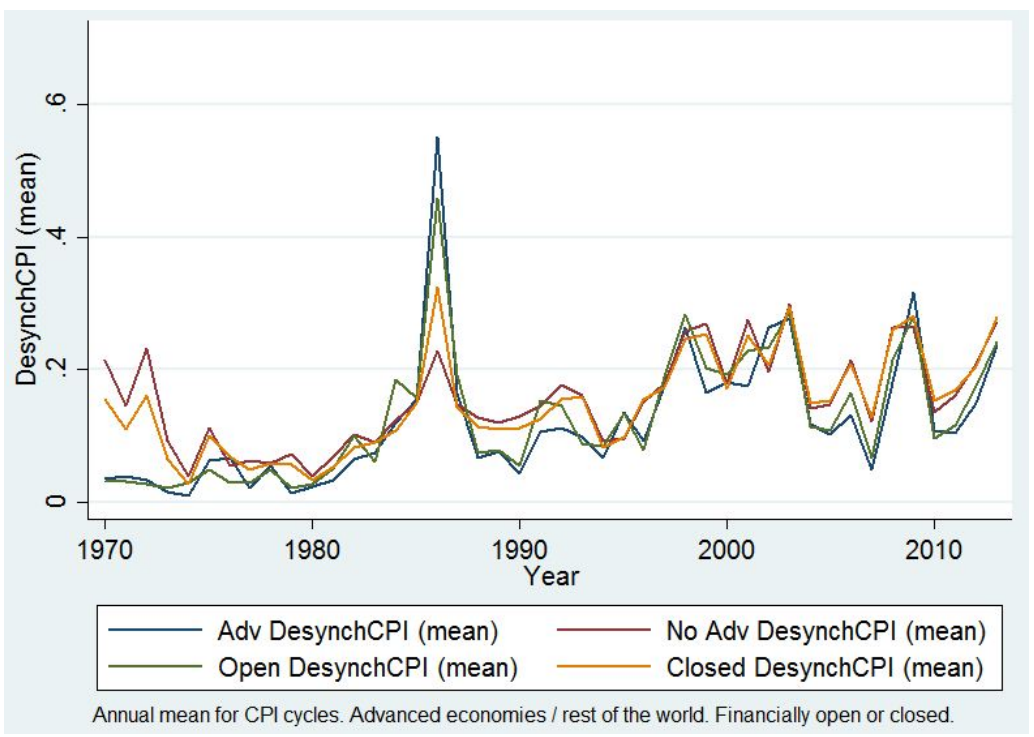

Figure A.2 - Various Inflation cycles desynchronization. 


\section{Appendix 3: Stylized Facts}

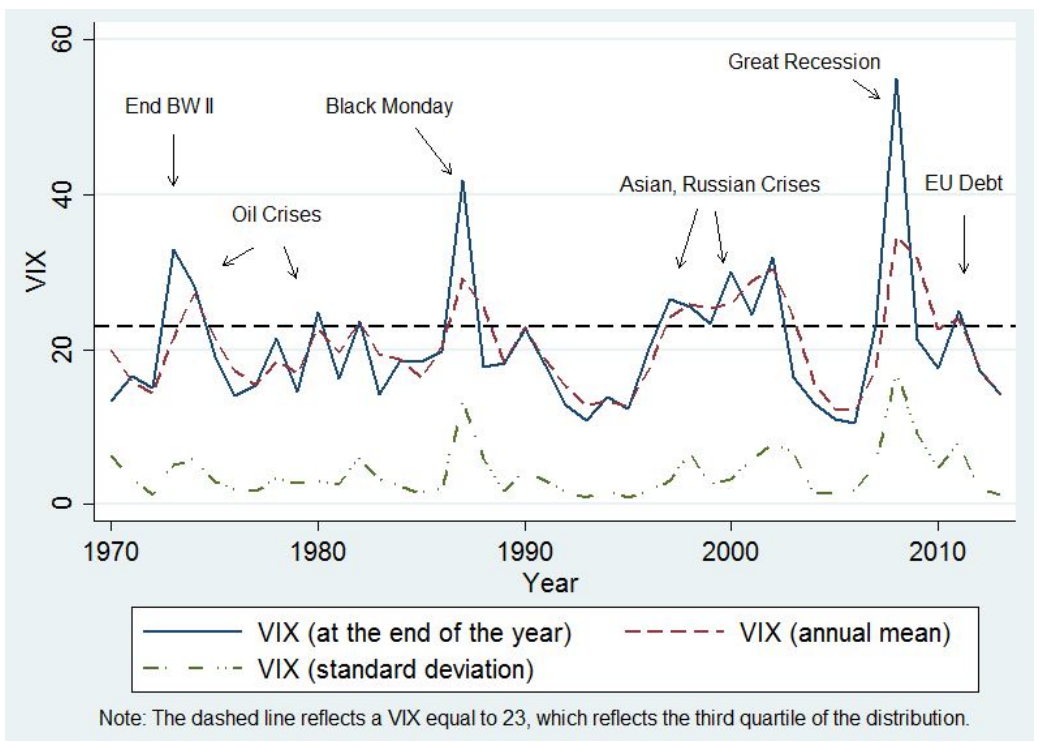

Figure A.3 - The Global Financial Cycle: various measures and threshold.

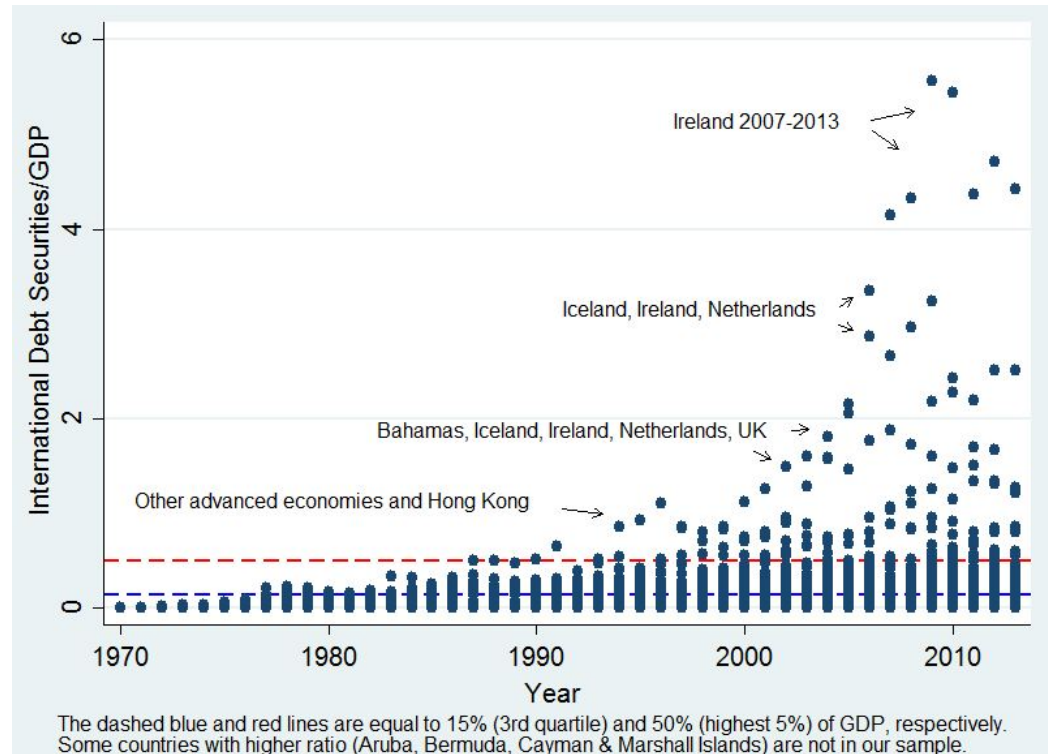

Figure A.4 - The growing influence of Global Investors. 


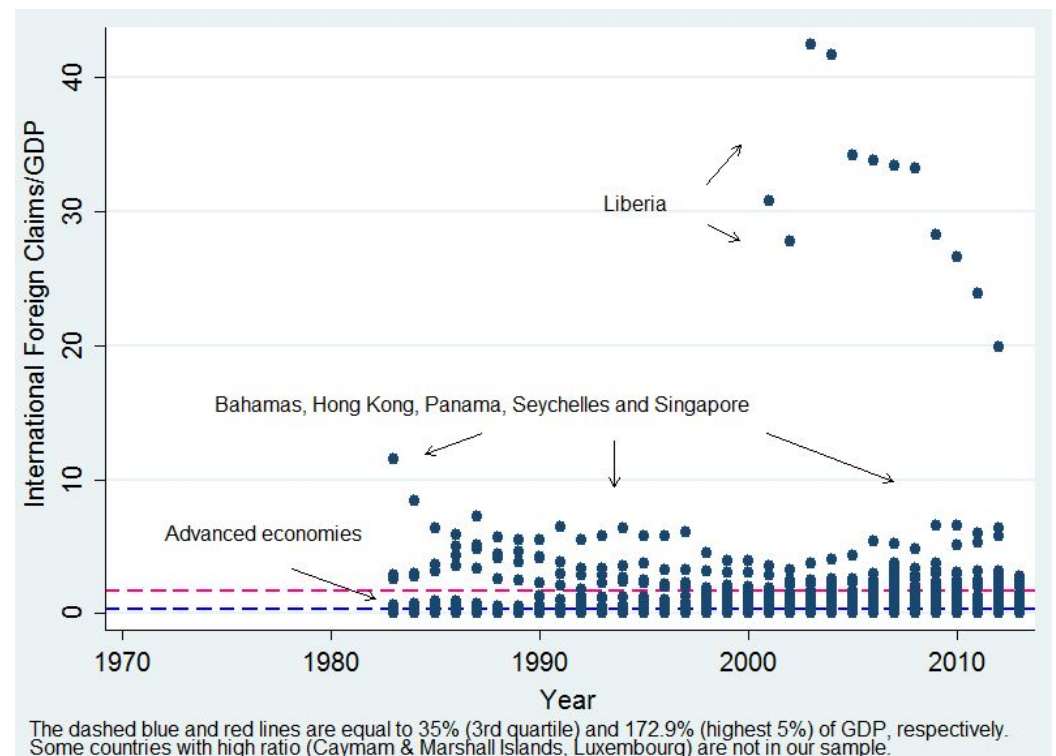

Figure A.5 - The large influence of Global Banks.

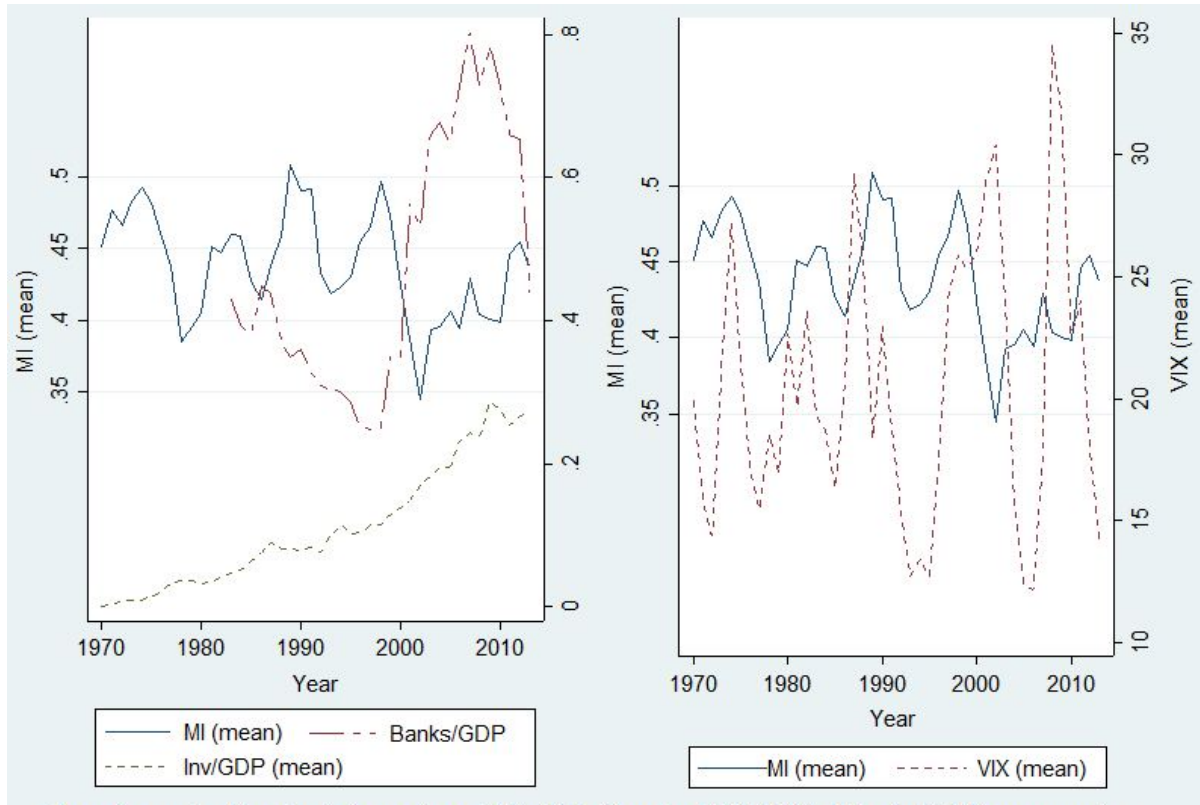

Annual mean for Monetary Independence, VIX, Global Investors/GDP, Global Banks/GDP in our sample

Figure A.6 - Does the Global Financial Cycle affect the trend of monetary policy independence? 